\title{
LA DECLARACIÓN DE DERECHOS EN LOS NUEVOS ESTATUTOS DE AUTONOMÍA
}

\author{
RAÚL CANOSA USERA \\ Catedrático de Derecho Constitucional. \\ Universidad Complutense de Madrid
}

SUMARIO

I. Reformas estatutarias y ¿federalización de los derechos?

II. Legitimación constitucional de la declaración estatutaria de derechos. ¿Una mutación del régimen constitucional de los derechos fundamentales?

III. Panorama de los derechos estatutarios.

IV. ¿Repetir, concretar, o suplir?

V. ¿Son derechos fundamentales?

VI. Sujetos activos y pasivos de los derechos estatutarios.

VII. Articulación de los derechos estatutarios con los derechos constitucionales.

VIII. Garantías de los derechos estatutarios.

IX. Conclusiones.

\section{REFORMAS ESTATUTARIAS Y ¿FEDERALIZACIÓN DE LOS DERECHOS?}

El pregonado éxito de nuestro Estado autonómico ha conducido, paradójicamente, a lo que parece un generalizado proceso de reformas estatutarias y de aprobación de nuevos estatutos de autonomía. La mudanza se extiende en una nueva escalada centrífuga que hará las delicias de los partidarios del principio de subsidiariedad. Las Comunidades autónomas se sienten capaces de ocuparse de más asuntos, también de los derechos, así que una de las no- 
vedades más llamativas de los recientes estatutos es la de incluir cartas recogiéndolos.

No han sido las declaraciones estatutarias de derechos lo que más polvareda ha levantado, incluso algunas han sido aprobadas por la casi unanimidad de los respectivos parlamentos y por las Cortes Generales. Sólo la declaración catalana ha sido impugnada, más por sus peculiaridades - que no presentan otras - y por venir incluida en un estatuto acerca de algunos de cuyos rasgos, de dudosa constitucionalidad, habrá de pronunciarse el TC. En el nuevo proceso descentralizador estas declaraciones de derechos no son, pues, ni tan polémicas ni tan perturbadoras como otras novedades estatutarias. Están, sin embargo, siendo discutidas por la doctrina, así que este trabajo es una modesta aportación a ese debate.

Ceñiré mi análisis a las declaraciones de derechos de los cinco estatutos ya aprobados al cierre de este trabajo: el valenciano (L.O. 1/2006 de 10 de abril), el catalán (L.O. 6/2006, de 19 de julio), el balear (L.O. 1/2007, de 28 de febrero), el andaluz (L.O. 2/2007, de 19 de marzo) y el aragonés (L.O. 5/2007, de 20 de abril), así como a las propuestas de reforma o de nuevos estatutos en fase de tramitación en las Cortes Generales. Los nuevos estatutos contienen también deberes y principios rectores para orientar las políticas autonómicas, y estos principios inciden en los mismos ámbitos donde se proclaman derechos, de tal suerte que el futuro legislador autonómico se verá constreñido ${ }^{1}$ a desarrollar los derechos y a ocuparse de los ámbitos donde estos se ejercen conforme a esos principios declarados. Derechos y principios operan así al unísono condicionando al legislador autonómico según su propia y modulada eficacia normativa. Hecha esta aclaración advierto que, en este trabajo, me ocuparé sólo de las declaraciones de derechos cuya problemática, aunque relacionada con la de los principios rectores, es específica y susceptible de tratamiento autónomo.

Las declaraciones estatutarias de derechos han sido objeto de críticas ${ }^{2}$ desde diferentes puntos de vista e, incluso aceptando su constitucionalidad, se ha dudado de su conveniencia. ${ }^{3}$ Sin duda la inclusión en los estatutos de declaraciones de derechos constituye una radical novedad que aproxima nuestro

1 Víctor FERRERES COMELLA destaca que, al petrificar los derechos estatutarios, pierde autonomía el legislador autonómico, lo que no beneficia el autogobierno, Derechos, deberes y principios en el nuevo Estatuto de Autonomía de Cataluña, CEPC, Madrid, 2006, p. 19. Luis María DÍEZ-PICAZO, por su parte, apunta que se cierra, sin legitimación constitucional para hacerlo, el proceso democrático impidiendo al legislador futuro tomar las decisiones que desee, en Revista Española de Derecho Constitucional, núm. 78 (2006), p. 71.

2 La más acerada acaso sea la de Lorenzo MARTíN RETORTILLO que consideran las declaraciones "operaciones oportunistas" promovidas por "progresistas de salón", "Derechos Humanos y Estatutos de Autonomía", en Aranzadi Tribunal Constitucional, núm. 3, 2006, p. 14.

3 Duda que expresa Paloma BIGLINO CAMPOS, "Los espejismos de la tabla de derechos", en Derechos, deberes y principios, CEPC, Madrid, 2006, p. 44. Javier GARCÍA ROCA también expresa sus dudas y, en todo caso, critica la excesiva extensión de la declaración catalana, "El riesgo de generalización de las asimetrías en las reformas estatutarias", en Luis ORTEGA (ed.), La reforma del Estado autonómico, CEPC, Madrid, 2005, p. 101. 
sistema de protección de la libertad a los modelos federales. En efecto, suele ser frecuente que los Estados federales ofrezcan una doble protección (federal y estatal) de los derechos, prevaleciendo, en caso de menor protección estatal, ${ }^{4}$ la protección federal, de tal suerte que nunca las garantías federales pueden ser disminuidas por la protección estatal. En el caso español la protección de los derechos venía siendo reservada al Estado, por un lado, porque la tutela jurisdiccional sólo provenía, y así seguirá siendo pesar de los cambios estatutarios, del poder judicial estatal ${ }^{5}$ y del Tribunal Constitucional, y, por otro, porque del juego de diversos preceptos constitucionales (sobre todo de los artículos 81.1 y 149.1.1) se desprendía que el legislador principal de los derechos fundamentales era el Estado. En definitiva, nuestro sistema de derechos era el propio de un Estado unitario.

Es cierto que el Tribunal Constitucional abandonó pronto (STC 37/1981) su primera opinión (STC 25/1981) de que los derechos fundamentales no se veían afectados por la estructura territorial del Estado para admitir la incidencia en ellos de la legislación autonómica. De los preceptos constitucionales y en especial del artículo 149.1.1 CE, el Tribunal Constitucional ha inferido el ámbito estatal de la legislación sobre derechos fuera del cual pueden incidir las Comunidades autónomas. ${ }^{6}$ Así las cosas, dadas las peculiaridades de nuestro sistema, el derecho comparado no puede, si más, legitimar constitucionalmente las declaraciones estatutarias que han de venir justificadas a la luz de la Constitución. ${ }^{7}$

Pero esa posible incidencia de la legislación autonómica en los derechos no había cristalizado en su declaración estatutaria, pues lo verdaderamente novedoso de la aparición de cartas estatutarias de derechos es que, por primera vez, el legislador estatuyente introduce declaraciones sistemáticas de derechos en una fuente nunca antes empleada para ello. Hasta la fecha la única

4 Se trata, pues, de una responsabilidad concurrente como explica G. Allan TARR, "Federalismo y protección de los derechos en Estados Unidos", en Miguel Ángel APARICIO (ed.), Derechos y libertades en los Estados compuestos, Atelier, Barcelona, 2005, p. 40. Ya es clásica la afirmación del núm. 51 de El Federalista en el que se habla de la doble seguridad para los derechos del pueblo que comporta el sistema federal. Josep María CASTELLÁ ANDREU, nos ofrece una buena síntesis de derecho comparado, «El reconocimiento y garantía de los derechos y libertades en los Estados compuestos. Una aproximación comparada", en APARICIO (ed.), ob. cit., p. 16 y ss., donde se analizan uno a uno varios modelos de Estados compuestos desde la perspectiva de esa duplicidad.

5 Aunque hay casos de federalismo (Austria y Bélgica) donde hay un solo poder judicial, como recuerda CASTELLÁ ANDREU, ob. cit., p. 30.

6 Como recuerda Carles VIVER I PI-SUNYER ya en las leyes autonómicas había derechos que ahora adquieren rango estatutario, "La reforma de los Estatutos de Autonomía", en La reforma de los Estatutos de Autonomía. Con especial referencia al caso catalán, CEPC, Madrid, 2005, p. 32.

7 Como apunta DíEZ-PICAZO, ob. cit., p. 67. El Consejo Consultivo de la Generalidad de Cataluña, en su dictamen, de 1 de septiembre de 2005, parece, por el contrario, utilizarlo como argumento justificativo. También Marc CARRILLO, "La declaración de derechos en el nuevo Estatuto de Autonomía de Cataluña: expresión de autogobierno y límite a los poderes públicos", en Derechos, deberes y principios en el nuevo Estatuto de Autonomía de Cataluña, CEPC, Madrid, 2006, p. 70. 
declaración de derechos era la de la Constitución. Se ofrecía así en este punto un panorama propio del Estado unitario; ahora se ofrecerá una suerte de federalización, es decir, una pluralidad de declaraciones. Este pluralismo declarativo presenta, por un lado, una vertiente simbólica que refuerza la posición constitucional de las Comunidades Autónomas. ${ }^{8}$ Al dotar a sus estatutos de una declaración de derechos, engrosando su parte dogmática, incorporan una materia típicamente constitucional, por más que los estatutos no sean constituciones y no puedan equiparse a tales. El efecto legitimador ${ }^{9}$ que siempre proporciona el reconocimiento de derechos se extiende particularmente a cada estatuto. Llegamos así a una duplicidad de declaraciones, estatal y autonómicas, pero no exactamente de corte federal ${ }^{10}$ porque ni las declaraciones estatutarias son efectivamente constitucionales ni se pretende una duplicidad de contenidos. Se busca más bien la complementariedad y no tanto la yuxtaposición aunque ésta resulte en ocasiones inevitable. Para la efectiva federalización habría que reformar la Constitución. ${ }^{11}$

El ciudadano, por su parte, se encuentra con dos declaraciones y con la posibilidad de hacer valer dos listas de derechos en lugar de sólo una como antes. Sin entrar ahora en un juicio cualitativo, lo cierto es que al sujeto se le han reconocido más derechos y que todos ellos puede, en principio, hacerlos valer. Sin embargo, no todos los ciudadanos podrán, a partir de ahora, hacer valer los mismos derechos pues si bien podrán invocar siempre y en cualquier lugar los proclamados en la Constitución, sólo los ciudadanos de la respectiva Comunidad estarán legitimados para invocar los derechos estatutarios respectivos. Se introduce así en el sistema español de derechos la desigualdad propia de casi todos los Estados compuestos y, como en éstos, se provocará una asimetría ${ }^{12}$ porque serán diferentes las declaraciones estatutarias. Esta asimetría no será producto de una autonomía constituyente, de la que carecen las CCAA, sino, al menos parcialmente, de la voluntad del legislador estatal. ${ }^{13}$ La igualdad entre los españoles descansará, como ahora, en el status de libertad asegurado por la Constitución, expresión primera de un orden de valores compartido, ${ }^{14}$ pero cada ciudadano tendrá en su Comunidad más o

8 CASTELLÁ resalta esta dimensión simbólica de las declaraciones de derechos en las constituciones de los entes federados, ob. cit., p. 27.

9 Efecto que, en línea con el dictamen del Consejo Consultivo de la Generalidad, explica CARRILLO, ob. cit., p. 69.

10 Francecs de CARRERAS SERRA considera que la reforma catalana interrumpen un proceso de federalización en el que estaba embarcado nuestro Estado autonómico para iniciar "un viaje hacia ninguna parte", "Reflexiones sobre la propuesta de nuevo Estatuto de Cataluña", en Teoría y Realidad Constitucional, núm. 16 (2005), p. 79.

11 Como aclara FERRERES COMELLA, ob. cit., p. 16.

12 Contra las asimetrías en general se manifiesta GARCÍA ROCA que apuesta por cerrar el proceso con una reforma de la Constitución, «El riesgo...”, ob. cit., pp. 92 y ss.

13 DÍEZ-PICAZO habla de un legislador estatal "esquizofrénico" que puede legislar para una CA lo contrario de lo que legisla para otra, ob. cit., pp. 72 y ss.

14 BARCELÓ explica bien como la dimensión axiológica de los derechos, como factor de integración, limita la descentralización, ob. cit., p. 123. En parecido sentido Joaquín BRAGE CAMA- 
menos derechos estatutarios, o ninguno si su estatuto no los contempla. Se tratará de la consecuencia lógica de un Estado compuesto, solemnizada en los mismos estatutos de autonomía. Estos no habían servido hasta ahora para introducir esas diferencias que se producían sólo cuando la respectiva Comunidad ejercía sus competencias y al hacerlo incidía en el ejercicio de los derechos pudiendo introducir diferencias de trato. A la pluralidad, ya existente, alimentada por las declaraciones internacionales y comunitarias, ${ }^{15}$ se suman ahora las variadas declaraciones estatutarias.

Si las declaraciones estatutarias de derechos no suponen, como los artículos 37.4 del Estatuto catalán, 13.3 del balear, 13 del andaluz y 6.3 del aragonés establecen, alteración de la distribución competencial, esto significa que la regulación autonómica de los derechos no conforma por sí sola una competencia nueva y, en puridad, nada habrá cambiado. Sin embargo, no puede dejar de tener consecuencias el que los legisladores autonómicos desarrollen ordenadamente los derechos estatutarios. El efecto desborda lo puramente simbólico, es también jurídico aunque con un alcance todavía sin determinar y que analizaremos después.

¿Son constitucionalmente legítimas las declaraciones estatutarias de derechos? En otras palabras ipueden los estatutos de autonomía proclamar derechos? Y si pueden ¿̇se altera el régimen constitucional de los derechos que ha funcionado hasta ahora? ¿Son fundamentales los derechos estatutarios? ¿Reiteran, integran o complementan la declaración estatal? ¿Cómo se articulan con ésta? Y, por último, ¿cómo se protegen los derechos estatutarios? Estas son las principales interrogantes que me propongo abordar en estas páginas.

\section{LEGITIMACIÓN CONSTITUCIONAL DE LA DECLARACIÓN ESTATUTARIA DE DERECHOS ¿UNA MUTACIÓN DEL RÉGIMEN CONSTITUCIONAL DE LOS DERECHOS FUNDAMENTALES?}

Como en otros ámbitos, en el de los derechos también hemos evolucionado desde un entendimiento unitario o cuasiunitario a otro federal o cuasifederal, cuya última manifestación serían las declaraciones estatutarias de derechos con las que se procura que la norma cimera del ordenamiento autonómico reproduzca los contenidos de una constitución y proclame derechos. Los estatutos por esta vía se "Constitucionalizan", incorporan una típica

ZANO, "Algunas breves consideraciones sobre los límites a los derechos fundamentales en el Estado autonómico", en Gerardo RUIZ RICO RUIZ (coord.), La reforma de los Estatutos de Autonomía. Actas de IV Congreso Nacional de la Asociación de Constitucionalistas de España, Tirant lo Blanch, Valencia, 2006, pp. 189 y ss. CASTELLÁ advierte la aparente contradicción entre la tendencia generalizadora de los derechos y la diversidad que introducen los Estados compuestos, ob. cit., p. 13.

15 La protección "multilevel" de los derechos que explica Maurizio FIORAVANTI, "Estado y Constitución", en El Estado moderno en Europa, Trotta, Madrid, 2004, p. 40. A la que también se refiere Francisco BALAGUER CALLEJÓN (Coord.), El nuevo Estatuto de Andalucía, Madrid, Tecnos, 2007, p. 34 . 
materia constitucional, pero no son constituciones ${ }^{16}$ y eso tiene sus consecuencias de orden práctico, como veremos más adelante. Esta situación - federalización material sin su formalización - provoca problemas de entendimiento y de funcionamiento de nuestra descentralización política, a los que ahora se sumará la concurrencia de la protección autonómica de los derechos. Pues no es lo mismo que la legislación autonómica incida sobre los derechos a que los nuevos estatutos vengan a reconocerlos y asignen a los poderes propios la tarea concreta de desarrollarlos y protegerlos. Se ha producido un cambio cualitativo: de la mera incidencia hemos pasado a la concurrencia de reconocimientos de los derechos. Y para comenzar, el legislador autonómico recibe la encomienda expresa o tácita de desarrollar los derechos estatutarios, desarrollo que resulta por lo demás indispensable vista la naturaleza prestacional de buena parte de los derechos estatutarios proclamados.

En definitiva, en el régimen constitucional de los derechos fundamentales, los nuevos estatutos introducen una radical transformación al consagrar la concurrencia de las Comunidades en el reconocimiento y protección de los derechos. Lo primero que debe aclararse es si esta modificación es constitucional. La respuesta a esta pregunta puede hallarse recordando cuál es el régimen constitucional de los derechos y comprobando si las declaraciones estatutarias encajan en ese régimen, bien que alterándolo sustancialmente. No hay duda de que, en cualquier Estado, la igualdad entre los ciudadanos viene asegurada mediante el reconocimiento a todos de derechos fundamentales. Sin embargo, en los Estados compuestos, singularmente los federales, esa igualdad en la libertad no excluye diferencias debidas a la existencia de declaraciones de derechos estatales. Así las cosas, la igualdad no puede ser, en los Estados compuestos, absoluta porque hay derechos, muchas veces distintos, en los diversos Estados, derechos que por añadidura poseen también rango constitucional.

Al margen de la conveniencia de declarar derechos en los Estatutos, ${ }^{17}$ oportunidad política que se formaliza legítimamente en las decisiones mayoritarias de las instituciones llamadas a apreciarla, lo que debemos plantearnos es la legitimidad constitucional de tal novedad. Al menos parece claro, incluso para los más fervorosos partidarios de la novedad, que la completa federalización no es posible por la diversa función que el estatuto de autonomía

16 Santiago MUÑOZ MACHADO advierte que tan oronda parte dogmática acerca los estatutos a la forma de las constituciones por más que no lo sean, "El mito del Estatuto-Constitución", en Luis ORTEGA ÁlVÁREZ, (dir.), La reforma del Estado Autonómico, CEPC, 2005, p. 74. BIGLINO CAMPOS se refiere a esta apariencia de constitución que presenta el nuevo estatuto catalán y que ella denomina "espejismo", ob. cit., pp. 41 y ss. Jesús GARCÍA TORRES también critica esa apariencia, "Los derechos estatutarios en la propuesta catalana de reforma", El Estado autonómico. Actas de las XI Jornadas de la Asociación de Letrados del Tribunal Constitucional, CEPC, Madrid, 2006, p. 66. FERRERES COMELLAS, por su parte, considera errónea la equiparación entre estatuto y constitución subestatal, ob. cit., pp. 12 y ss.

17 Paloma BIGLINO CAMPOS considera constitucionalmente posible una tabla de derechos estatutaria pero duda de su conveniencia, ob. cit., p. 48. 
cumple en nuestro sistema de fuentes ${ }^{18}$ como norma definidora del reparto de competencias entre el Estado y la CA respectiva, ${ }^{19}$ y que se gesta, como norma pactada, entre esos dos sujetos. Es lógico que el Estado participe en el proceso de elaboración y aprobación de los estatutos en la medida en la que es directamente concernido por ellos pues precisan la proyección de sus competencias en el ámbito de la CA concreta. ${ }^{20}$

Tiene pleno sentido que el art. 147.1 CE disponga que el Estatuto de autonomía es la norma institucional básica de la CA, y a esta función atribuida habremos de remitir todos los argumentos que empleemos en lo sucesivo. Hay que preguntarse si las declaraciones estatutarias responden a esa función o si obligan a replantear el entendimiento de lo que los estatutos significan en nuestro sistema de fuentes. ${ }^{21} \mathrm{El}$ modo de aprobación de los Estatutos, reflejo como hemos visto de la función que desempeñan en el ordenamiento, no es un dato secundario porque, en los demás Estados compuestos, en Italia ${ }^{22}$ incluso desde la reforma constitucional de 1999, las constituciones o estatutos de los entes descentralizados son aprobados por estos sin concurso del ente central y no cumplen la función distribuidora de competencias que los estatutos españoles tiene asignada.

Los términos del debate en torno a la constitucionalidad de la novedosa declaración estatutaria de derechos quedaron en esencia fijados en un primer momento con los argumentos ofrecidos por el Consejo Consultivo de la Generalidad de Cataluña en su dictamen de 1 de septiembre de 2005. En torno a ellos ha ido creciendo la polémica y se han aportado argumentos nuevos que la han enriquecido. Las justificaciones del citado dictamen ${ }^{23}$ son las siguientes: Es frecuente y desde luego normal en los Estados compuestos encontrar declaraciones de este tipo; estos derechos sirven de límite e impulso a la acción de los poderes públicos de la CA; su desarrollo, promoción y protección están vinculados al ejercicio de las competencias propias de la CA; se respetan los límites constitucionales puesto que se deja intacta la reserva de ley orgánica (art. 81.1 CE) y la competencia estatal ex art. 149.1.1 CE; además, la declaración estatutaria conecta con la función del estatuto pues orienta y limita el ejercicio de las competencias autonómicas.

Quedaba así justificada la declaración catalana que venía a presentarse como expresión de autogobierno. ${ }^{24}$ Tal expresión tendrá, pues, que encajarse

18 Cfr. para todo César AGUADO RENEDO, El Estatuto de Autonomia y su posición en el sistema de fuentes, CEPC, Madrid, 1996, pp. 319 y ss.

19 Función que, como recuerda FERRERES, corresponde a la Constitución federal y no a las Constituciones estatales en un Estado federal, y que pone de relieve al referirse a la reforma catalana, ob. cit., p. 13. También CARRERAS SERRA, ob, cit., pp. 56 y ss.

20 Es lógico que el Estado participe en la gestación del Estatuto por cuanto que en él se determina el alcance de sus competencias respecto de la CA en concreto, FERRERES, ob. cit., p. 13.

21 Pregunta que se hace TAJADURA, ob. cit., p. 63.

22 Cfr. respecto al caso italiano Emanuele ROSSI, "Derechos de libertad y estatutos regionales. La situación italiana", en APARICIO (ed.), ob. cit., pp. 201 y ss.

23 Glosadas por CARRILLO, ob. cit., pp. 68 y ss. A las que se adhiere VIVER, ob. cit., pp. 30 y ss.

24 Tal como la define CARRILLO, ob. cit., p. 72. 
en el ejercicio del derecho a la autonomía consagrado por el art. 2 CE. Entre los contenidos de este derecho habría que incluir el de proponer a la Cortes un estatuto con declaración de derechos, ello a pesar de que la Constitución no prevea, a favor de las CCAA, una competencia específica al respecto, ni los estatutos nuevos la contemplen aprovechando la cláusula de residualidad establecida en el art. 148.3 CE. Por añadidura, se podría argüir que la declaración estatutaria de derechos sería expresión del pluralismo político (art. 1.1 CE) en su vertiente de pluralismo territorial. ${ }^{25}$

Este bien trabado armazón argumental ha sido, como era de esperar, objeto de críticas y reticencias. Para empezar, se ha afirmado ${ }^{26}$ que no es expresión de autogobierno la imposición estatal (al fin y al cabo el estatuto es aprobado mediante una ley estatal) de vínculos para el legislador autonómico: También se ha dicho que el autogobierno ha de disfrutarse en el marco de la Constitución que no sería otro que el previsto en el art. $147 \mathrm{CE}^{27}$ y en otros preceptos de la Constitución. Tampoco la apelación al derecho comparado es suficiente porque nuestra descentralización difiere, en puntos esenciales, de la propiamente federal. ${ }^{28}$ Veamos ahora si es posible a la luz de nuestra Constitución declarar derechos en los estatutos de autonomía y, de ser posible, que alcance puede tener esta declaración.

El referente constitucional más preciso lo brinda el art. 147.2 CE que detalla los contenidos que habrán de incorporar los estatutos. No menciona los derechos y esta omisión ha sido interpretada hasta la fecha como no autorización para incluirlos o, al menos, ha disuadido al legislador estatuyente de introducir declaraciones. De la literalidad del art. $147 \mathrm{CE}$ se infiere sin dificultad que el constituyente concibió los estatutos, sobre todo, como normas orgánicas de cada Comunidad pues los define institucionales y se refiere a sus contenidos en clave orgánica y procedimental para exigirles la determinación de las competencias asumidas. Ya en un primer momento, sin embargo, algunos estatutos parecían desbordar el elenco de contenidos mencionado en el artículo $147.2 \mathrm{CE}$, incluso se referían con frecuencia a los derechos fundamentales aunque remitiéndose a los constitucionales ${ }^{29}$ o reproduciendo la

25 Lo apunta ROSSI para el caso italiano, ob. cit., p. 214, y AGUADO para el caso español, ob. cit., p. 355.

26 FERRERES, ob. cit., pp. 20 y 21.

27 DÍEZ-PICAZO duda de que estas declaraciones sean expresión de autogobierno, pero éste ha de encauzarse siempre por la senda constitucional, ob. cit., p. 65.

28 Como resaltan GARCÍA TORRES, ob. cit., p. 71, y DÍEZ-PICAZO, ob. cit., p. 66.

29 Dejando a salvo la afirmación que incluyeron todos los antiguos estatutos, salvo el balear, de que los ciudadanos de la respectiva Comunidad son titulares de los derechos y deberes declarados por la Constitución, disposiciones que son perfectamente superfluas (art. 9.1 del Estatuto del País Vasco, art. 8.1 del ya derogado Estatuto de Cataluña, art. 4.1 del Estatuto de Galicia, art. 11 del ya derogado Estatuto andaluz, art. 9.1 del Estatuto del Principado de Asturias, art. 5.1 del Estatuto de Cantabria, art. 7.1 del Estatuto de La Rioja, art. 9.1 del Estatuto de la Región de Murcia, art. 2 del Estatuto de la Comunidad Valenciana, art. 6.1 del Estatuto de Aragón, art. 4.1 de la Comunidad de Castilla-La Mancha, art. 5.1 del Estatuto de Canarias, art. 6 de la Ley de Amejoramiento del Régimen Foral de Navarra que establece que los navarros gozan de los mismos de- 
cláusula de igualdad sustancial del art. 9.2 CE. Ante la situación creada, el artículo 147.2 CE tuvo que interpretarse, y así lo hizo el Tribunal Constitucional (STC 89/1984) como un precepto de mínimos: el contenido indispensable de un estatuto, no tanto como la reserva absoluta a favor de estatuto. De haberse optado por esta última opción, sólo las materias mencionadas y no otras podrían haberse incluido en los estatutos. Al desecharse la interpretación restrictiva se liberaba al poder estatuyente para actuar con mayor discrecionalidad, con los únicos límites, claro está, de la Constitución. Había de recoger forzosamente en los estatutos los contenidos mínimos previstos en el art. 147.2 CE, pero podrían incluirse otros.

Todos los que se han pronunciado acerca de este desbordamiento de la escueta reserva contemplada en el art. 147.2 CE aceptan la conclusión del TC, según la cual esa reserva no es absoluta sino relativa, y todos admiten que ello no supone una ilimitada libertad del legislador estatuyente para incluir cualquier cosa en un estatuto, siempre que no contradiga materialmente la Constitución, sino que hay límites formales que tienen que ver con la función del estatuto en nuestro sistema de fuentes. Discrepan, claro está, a propósito de si un estatuto puede incorporar una parte dogmática, con carta de derechos incluida.

Así pues hay unanimidad entorno al alcance de la reserva del art. 147.2, como reserva e mínimos y también coinciden en que la propia Constitución abre la puerta al tratamiento estatutario de otras materias. ${ }^{30}$ Los estatutos podrán ocuparse, ya lo hacen en muchos casos, de la lengua propia (art. 3.2 CE), de los símbolos autonómicos (art. 4.2 CE), de sus tributos (art. 133.2 CE), de la participación de la CA en la recaudación, gestión o liquidación de los recursos tributarios estatales (art. 156.2 CE), de los posibles convenios entre CCAA (art. 145.2), de la participación de las CCAA en la organización de las demarcaciones judiciales (art. 152.1 CE), y de la creación y organización de las circunscripciones territoriales propias a partir de la agrupación de municipios (art. 152.3 CE).

Todos los preceptos citados acaban conformando un contenido adicional y posible que se sumaría al contenido necesario, mínimo, previsto en el art. 147.2 CE. Para algunos la suma del contenido mínimo y del adicional, expresamente amparado en los citados preceptos, formaría el contenido constitucionalmente tasado que no podría rebasarse ${ }^{31}$ todo él relacionado con lo or-

rechos que el resto de los españoles, art. 6.1 del Estatuto de Extremadura, art. 7.1 del Estatuto de la Comunidad de Madrid, art. 8.1 del Estatuto de Castilla y León, art. 5.1 del Estatuto de Ceuta y art. 5.1 del Estatuto de Melilla). Luis María DíEZ-PICAZO resalta que ya los antiguos estatutos contenían algunos derechos pero que no pasaban de ser normas programáticas, lo que no pretenden ahora las nuevas declaraciones estatutarias, “Pueden lo Estatutos de autonomía declarar derechos, deberes y principios?", ob. cit., p. 64.

30 CARRILLO las enumera, ob. cit., pp. 67 y ss. También, desde posiciones doctrinales radicalmente enfrentadas, DÍEZ-PICAZO, ob. cit., p. 6. Asimismo AGUADO, ob. cit., pp. 316 y ss.

31 Como defienden GARCÍA TORRES, ob. cit., p. 67, y DÍEZ-PICAZO, ob. cit., p. 65. También AGUADO que distingue entre contenido mínimo y contenido reservado, ob. cit., pp. 301 y ss. 
ganizativo y subordinado a la función institucional que el art. 147.1 CE asigna a los estatutos. ${ }^{32}$ De lo que resulta que los estatutos no están destinados a poseer una parte dogmática, ${ }^{33}$ en donde se declaren principios, derechos y deberes vinculantes para los poderes públicos, puesto que la función del estatuto es crear y organizar las instituciones de autogobierno, atribuir competencias a la comunidad concernida y, al hacerlo, delimitar la proyección de las competencias estatales. No habría, pues, ni reserva constitucional explícita ni implícita a favor de los estatutos de la materia derechos. ${ }^{34}$ Los principios, derechos y deberes a los que están sometidas las instituciones autonómicas serán las que prevea la CE. Así que aquellas referencias a principios, derechos y deberes que ya recojan los estatutos desde la primera hora, poseen sólo un carácter programático, ${ }^{35}$ distinto del directamente vinculante que se prevé para los derechos recién declarados, al menos en los estatutos catalán y andaluz.

La conclusión a la que habría que llegar si aceptáramos este punto de vista, es que la declaración de derechos únicamente puede hacerse en la Constitución, porque hay una reserva en su favor de esta materia. ${ }^{36}$ Bastaría, pues, este argumento formal para considerar inconstitucional cualquier declaración estatutaria de derechos vinculante para los poderes públicos.

Frente a los buenos argumentos expuestos, ${ }^{37}$ la manera de rebatirlos ha consistido en conectar esa parte dogmática, y en especial la declaración de derechos, con el contenido necesario y adicional de los estatutos. ${ }^{38}$ Los principios, derechos y deberes se proclaman para impulsar, orientar y limitar el ejercicio de las propias competencias y, en este sentido, adquieren la dimensión institucional requerida por el art. 147.1 CE.

Es obvio que, amén de la propia Constitución, recaen sobre el legislador autonómico los límites derivados del propio estatuto de autonomía. Con los nuevos estatutos que contemplan derechos, las Comunidades respectivas tienen que cumplir una misión que antes no se recogía expresamente: la de proteger los derechos estatutarios. En esta tarea, las Comunidades habrán de legislar y emplear todas sus competencias para protegerlos, desplegando políticas adecuadas de promoción. Esta novísima tarea, tan importante, ¿comporta competencias específicas? La respuesta es no, como establecen los ar-

32 Cfr. GARCÍA TORRES, ob. cit., pp. 68 y ss. AGUADO, ob. cit., pp. 355 y ss.

33 Así lo afirman, entre otros, AGUADO, ob. cit., p. 365, MUÑOZ MACHADO, Derecho público de las Comunidades Autónomas, Civitas, Madrid, 1982, pp. 296 y ss.

34 Inexistencia que defiende AGUADO, ob. cit., p. 335.

35 En la interpetación de DÍEZ-PICAZO, ob. cit., pp. 63 y 64.

36 A esta conclusión llegan GARCÍA TORRES, ob. cit., p. 73. DÍEZ-PICAZO considera que la única apertura es la prevista en el art. 10.2 CE y se refiere sólo a la interpretación, ob. cit., p. 71.

37 Que valora BIGLINO, aunque opine que las declaraciones estatutarias de derechos no son inconstitucionales, ob. cit., p. 44.

38 Así lo explica CARRILLO, ob. cit., pp. 65 y ss. También MARTÍNEZ SOSPEDRA, "Derechos y Estado autonómico. Nota para una hipótesis de trabajo", en Cuadernos Constitucionales de la Cátedra Fadrique Furiol Ceriol, num. 34/35 (2001), pp. 309 y ss. También GARCÍA ROCA, "El riesgo...", ob. cit., p. 101. 
tículos $37.4^{39}$ (introducido en la tramitación en el Congreso de los Diputados) del Estatuto catalán, 13.3 del balear, 13 del andaluz y 6.3 del aragonés al disponer que el reconocimiento de derechos en el estatuto no supone una alteración del régimen de atribución de competencias ni la creación de títulos competenciales nuevos o la modificación de los existentes.

Es curioso que los demás estatutos, ya aprobados o que se están tramitando no se contemple esta cautela que resulta elemental pero que, a pesar de su claridad, no evitará conflictos competenciales en el futuro. Además, llama la atención que su literalidad se parezca tanto a la del artículo 49.2 de la Carta de Derechos Fundamentales de la Unión Europea, donde también se establece que los derechos fundamentales comunitarios no implican para la Unión competencias nuevas distintas de las expresamente consagradas en los tratados.

Según lo anterior, cuando las comunidades dicten normas desarrollando los derechos estatutarios, lo que por lo demás es imprescindible puesto que en su mayor parte los derechos estatutarios son prestacionales, habrá de entenderse que ejercerán competencias específicas en materias donde tales derechos se proyecten. Así las cosas, cuando el parlamento de Cataluña u otros aprueben leyes de desarrollo de los derechos estatutarios o cartas de derechos, como algún estatuto reclama, ejercerán simultáneamente una pluralidad competencias porque no disponen de ninguna concreta, según lo establece el propio estatuto, que dé cobertura conjunta a semejante acto legislativo. De esta suerte el mandato de elaboración de la carta de derechos que en sí mismo contiene una reserva a favor de ley formal del parlamento, carece de relevancia competencial, lo mismo que sucede con el artículo 81.1 de la Constitución en relación con la actividad legislativa del Estado. Y del mismo modo que la legislación estatal sobre derechos ha de fundarse en una competencia específica o al menos en la contenida en el artículo 149.1.1 CE, las leyes autonómicas que desarrollen los derechos estatutarios habrán de presentar el correspondiente aval competencial que, en ausencia de precepto equivalente al artículo 149.1.1 CE, tendrá que ser un título específico en la materia.

Es por tanto muy novedoso también el nuevo vínculo que para el legislador autonómico comporta su sometimiento a los derechos estatutarios. Sin alteración de sus competencias debe ahora ejercerlas respetando y desarrollando los nuevos derechos proclamados. Va de suyo que el legislador autonómico de los derechos, además de estar constreñido por la Constitución y el propio Estatuto, lo está también por la legislación estatal que haya fijado las condiciones básicas del ejercicio de los derechos. Así, por ejemplo, la regu-

39 Cuya semejanza con el art. 51.2 de la Carta de Derechos Fundamentales de la Unión Europea ha resaltado CARRILLO, ob. cit. p. 82. Aunque la situación es distinta porque la Carta aspira a ser, así habría sido, de haberse aprobado el Tratado constitucional europeo, la norma más alta, primando sobre el derecho interno, y en consecuencia sobre la Constitución española, aspiración vetada a las declaraciones estatutarias. 
lación estatutaria de las asociaciones o de los derechos sanitarios o educativos no puede desconocer los contenidos básicos de tales derechos, establecidos en la ley estatal reguladora del derecho de asociación o las relativas a los derechos educativos y sanitarios. Esta vinculación no impide al legislador autonómico mejorar la protección del derecho que brinda la ley estatal, ya que ésta opera como mínimo de protección, pudiendo la ley autonómica imponer a los poderes públicos de la Comunidad un tratamiento mejor del derecho.

A falta de previsión constitucional expresa, o aceptamos la conexión de las declaraciones estatutarias con las competencias de las CCAA o concluye nuestro análisis porque deberíamos entender inconstitucional toda declaración estatutaria de derechos por infracción de la reserva de tal declaración a favor de la Constitución.

Admitida, en principio, la declaración estatutaria de derechos y que tal declaración no altera el reparto de competencias, hay que preguntarse ahora acerca de su posible extensión y naturaleza de los derechos declarados ¿Puede un estatuto declarar cualquier derecho o cabe inferir de la Constitución que no todos pueden ser declarados? ¿Cuáles son, en suma, los límites constitucionales de tal declaración?

Se han aplicado a las declaraciones estatutarias aprobadas y en tramitación los criterios que se aplican al legislador autonómico, orillando acaso que el autor de los estatutos es distinto y que no necesariamente el legislador estatuyente puede incidir del mismo modo en la materia de derechos. Se ha afirmado que ya muchos derechos ahora declarados se hallaban en leyes autonómicas y que su elevación de rango no hace otra cosa que comprometer al legislador autonómico. ${ }^{40}$ Como era de esperar, quienes consideran superada la barrera, a su juicio, infranqueable de la reserva máxima a favor de estatuto, admiten la incidencia de las leyes autonómicas en los derechos ${ }^{41}$ pero rechazan la del estatuyente. ${ }^{42}$ Los defensores de las declaraciones estatutarias parecen sugerir que si cabe incidencia del derecho autonómico infraestatutario en los derechos, como no va a ser posible que la norma cimera del ordenamiento autonómico pueda incidir en ellos. Además ya hay ejemplos como el brindado por el artículo 10.13 del Estatuto vasco, referido al derecho de asociación. ${ }^{43}$ Sin embargo, hay que puntualizar que esta referencia a ese derecho

40 CARRILLO, ob. cit., p. 65 y VIVER, ob. cit., p. 32, lo resaltan en tono elogioso. FERRERES, en cambio, en son de crítica porque tal petrificación de rango, limita el autogobierno, manifestado en la voluntad del Parlamento de la CA, ob. cit., pp. 17 y ss.

41 AGUADO desglosa las posibles incidencias como sigue: regular, en la medida de su competencia, derechos proclamados en la $\mathrm{CE}$, transformar en derechos subjetivos principios rectores del Capítulo III, título I CE, reconocer nuevos derechos no contemplados en la CE, ob. cit., p. 358.

42 De forma rotunda GARCÍA TORRES, ob. cit., p. 69. También DÍEZ-PICAZO, ob. cit. pp. 63 y ss.

43 Ejemplo que recuerda, en conexión con la STC 73/1998, BIGLINO, ob. cit., p. 45. Sin embargo, hay que puntualizar que la referencia al derecho se hace al regular una competencia recogida, ex art. 148.3 CE, en el Estatuto vasco (art. 10.13), y no puede considerarse técnicamente como una declaración semejante a las que ahora se analizan. No se declara un derecho sino que se atribuye una competencia expresa en relación con ciertas asociaciones. 
se hace al regular una competencia recogida, ex art. $148.3 \mathrm{CE}$ y no puede considerarse técnicamente como una declaración semejante a las que ahora se analizan. No se declara un derecho sino que se atribuye una competencia expresa en relación con ciertas asociaciones.

Nos enfrentamos así a un segundo escollo, también de carácter formal, como lo era el de la reserva de derechos en favor de la Constitución. Si admitimos que es posible la incidencia autonómica en los derechos - ya está consagrada la de las leyes autonómicas - incluso mediante declaraciones estatutarias, entonces habrá que ventilar si los mismos límites que pesan sobre el legislador autonómico pesan sobre el estatuyente, es decir, si, con independencia de si declaran o desarrollan derechos, los límites son los mismos. En principio hay que responder que sí, pues tales limitaciones ${ }^{44}$ están en la Constitución (salvo las que se contemplen en los estatutos y sólo vinculen al legislador autonómico ordinario) y vinculan tanto al legislador estatuyente como al autonómico. Veamos ahora cuáles son esos límites y cómo afectan al legislador estatuyente.

Pueden invocarse los siguientes preceptos de la Constitución: artículos 81.1, 138.2, 139.2 y 149.1.1. ${ }^{45}$ Según la jurisprudencia del TC, de los mencionados sólo el art. 149.1.1 CE atribuye al Estado una competencia general en materia de derechos. El artículo 149.1.1 CE establece que al Estado corresponde la competencia exclusiva para "La regulación de las condiciones básicas que garanticen la igualdad de todos los españoles en el ejercicio de los derechos y en el cumplimiento de los deberes constitucionales". Se proyecta así la igualdad, con una competencia estatal general, en la organización territorial del Estado. ${ }^{46}$

Es ésta la única regla competencial ${ }^{47}$ específica en materia de derechos a la que se suman otras competencias estatales específicas que permiten al Es-

44 Se refieren a estos límites, ya en relación con los nuevos estatutos VIVER, ob. cit., p. 53 , MUÑOZ MACHADO, "El mito....", ob. cit., p. 70, DÍEZ-PICAZO, ob. cit., p. 63, CARRILLO, ob. cit., pp. 73 y ss. Nuria GARRIDO CUENCA, "La reforma del Estatuto de Autonomía de Castilla-La Mancha", en ORTEGA, ob. cit., pp. 170 y ss. Miguel AGUDO ZAMORA, "La inclusión de un catálogo de derechos y deberes en el Estatuto de Autonomía de Andalucía", RUIZ RICO, ob. cit., pp. 355 y ss. Ya antes los había explicado AGUADO, ob. cit., pp. 336 y ss. Y lleva a afirmar a Luis LÓPEZ GUERRA que, dada la reserva prevista en el art. 81.1 CE, la "aplicación autónoma" del art. 149.1.1 CE se proyectará sobre todo al fijar las condiciones mínimas de los derechos sociales, "Consideraciones sobre las condiciones básicas el artículo 149.1.1 de la Constitución", en Alberto PÉREZ CALVO (coord.), Normativa básica en el ordenamiento jurídico español, INAP, Madrid, 1990, pp. 91 y ss.

45 Advierte José Antonio ALONSO DE ANTONIO que no es fácil hallar en derecho comparado una regla competencial como la contenida en el art. 149.1.1 CE, "Artículo 149.1", en Oscar ALZAGA (dir.), Comentarios a la Constitución española de 1978, EDERSA, Madrid, 2. a edición, 1999, p. 283.

46 Finalidad de la competencia que resalta ALONSO DE ANTONIO, ob. cit., p. 283. También Javier TUDELA ARANDA, Derechos constitucionales y autonomia politica, IVAP-Civitas, Madrid, 1994, pp. 134 y ss. Juan PEMÁN GAVÍN destaca como el TC no ha analizado las leyes autonómicas desde el art. 14 CE sino desde el art. 149.1.1 CE, Igualdad de los ciudadanos y autonomías territoriales, Civitas-Universidad de Zaragoza, Madrid, 1992, pp. 195 y ss. En el mismo sentido BRAGE, ob. cit., p. 195.

47 Acerca de ella y con carácter general, cfr. VVAA, La función del artículo 149.1.1 de la Constitución en el sistema de distribución de competencias, IEA, Barcelona, 1991. 
tado desarrollar e incidir en derechos concretos (por ejemplo en título previsto en el art. 149.1.30 respecto de los derechos educativos). Por su parte, el artículo 81.1 CE (la reserva de ley orgánica) ha sido interpretado por el TC en clave no competencial, ${ }^{48}$ es decir, el artículo 81.1 no atribuye al Estado una competencia para desarrollar los derechos reservados sino que "opera como una prolongación de los preceptos constitucionales que desarrolla". ${ }^{49}$ Además no son coextensos los ámbitos de esta reserva y los de la competencia recogida en el artículo 149.1.1 CE, ${ }^{50}$ de tal suerte que incluso la legislación orgánica habrá de conectarse con una competencia estatal concreta o, si no lo hubiera, con la contenida en el artículo 149.1.1 CE. ${ }^{51}$

El $\mathrm{TC}^{52}$ ha identificado restrictivamente el ámbito material de esta competencia con un mínimo común denominador en materia de derechos y deberes que puede fijar el legislador estatal para asegurar la igualdad en el ejercicio de los derechos y en el cumplimiento de los deberes constitucionales. ${ }^{53}$ Evita así el TC que este título se convierta en una competencia horizontal susceptible de aminorar significativamente las competencias autonómicas. Su ámbito queda, pues, reducido a la regulación de las posiciones jurídicas fundamentales, ${ }^{54}$ y no comprende una regulación acabada y completa del derecho. Además el artículo 149.1.1 CE sirve también como regla hermenéutica para modular el alcance de otras competencias estatales ${ }^{55}$ pero también y sobre todo de las competencias autonómicas, ahora más si cabe, tras las declaraciones estatutarias. Estas no pueden fijar el alcance del título estatal que queda intacto ${ }^{56}$ y seguirá produciendo los efectos pertinentes, así que la competencia estatal ex artículo 149.1.1 CE seguirá proyectándose en la vida del ordenamiento, sin que las declaraciones estatutarias de derechos le afecten, y seguirá condicionando de igual modo que antes la actuación del legislador autonómico.

48 Extremo este que explica muy bien Enrique LUCAS MURILLO DE LA CUEVA, "Delimitación de la competencia autonómica para la regulación de los derechos fundamentales", en Revista de Derecho Político, núm. 46 (1999), pp. 22 y ss. También PEMÁN, ob. cit., p. 215.

49 En palabras de Enrique LUCAS MURILLO DE LA CUEVA, ob. cit., p. 22.

50 Lo recuerda Enrique LUCAS MURILLO DE LA CUEVA, ob. cit., pp. 34 y ss. También BRAGE, ob. cit., p. 205.

51 BARCELÓ explica que el art. 149.1.1 CE habilita al Estado cuando éste carece de una competencia específica sobre determinados derechos, algunos de ellos reservados a ley orgánica, ob. cit., pp. 102 y ss. En parecidos términos lo explica PEMÁN, para quien la reserva del art. 81.1 CE no habilita competencialmente al Estado, que dispone de competencia exclusiva respecto de los derechos proclamados en los arts. 15, 17, 24 y 28 CE, competencia para dictar normativa básica en relación con los derechos reconocidos en los arts. 27, 23.2 y 20.1 CE, siendo necesaria la invocación del art. 149.1.1 CE para regular las condiciones básicas del resto de los derechos, ob. cit., p. 220.

52 Varios autores resumen y comentan la jurisprudencia del TC respecto del art. 149.1.1 CE: CABELLOS, ob. cit., pp. 89 y ss., TUDELA, ob. cit., pp. 135 y ss. y BRAGE, ob. cit., pp. 197 y ss., siendo una de las garantías constitucionales de la igualdad, LÓPEZ GUERRA, ob. cit., pp. 84 y 85.

53 Lo explican bien CABELLOS, ob. cit., pp. 23 y ss. y TUDELA, ob. cit., pp. 135 y ss.

54 Como recuerdan, BIGLINO, ob. cit., p. 48, CABELLOS, ob. cit., pp. 114 y ss. o BRAGE, ob. cit., pp. 197 y ss.

55 Señala BIGLINO, ob. cit., pp. 112 y ss.

56 Como bien precisa DÍEZ-PICAZO, ob. cit., pp. 64 y 65. 
En definitiva, el Estado posee en materia de derechos la competencia general de regular las condiciones básicas de su ejercicio y las competencias específicas en determinadas materias, debiendo emplear la ley orgánica o ley ordinaria (siempre una ley en virtud de la reserva contemplada en el artículo $53.1 \mathrm{CE}$ ) según el derecho que se regula. De lo anterior se desprende que a las Comunidades autónomas queda un espacio que no puede ocupar el legislador estatal: lo que no son condiciones básicas y, aunque en la medida en la que el Estado no las regule podrán las Comunidades incidir en ellas, según parece deducirse de la jurisprudencia de TC. De esta suerte más que regular un espacio material excluyente de toda intervención autonómica, el artículo 149.1.1 CE habilita al Estado para condicionar el ejercicio de las competencias autonómicas. ${ }^{57}$ Estamos así ante una especie de residualidad a favor de las Comunidades que era, empero, difícil de plasmar en los estatutos como reverso de la competencia contemplada en el artículo 149.1.1 CE. En efecto, el artículo 148.3 CE establece que "las materias no atribuidas expresamente al Estado... podrán corresponder a las Comunidades Autónomas en virtud de sus respectivos estatutos". Pero esta residualidad opera a través de otras competencias concretas $^{58}$ cuyo empleo permite a las Comunidades incidir en los derechos. Desde luego, las declaraciones estatutarias de derechos no se justifican en la citada residualidad ni, como hemos visto, atribuyen competencias.

Podría argüirse que los estatutos de autonomía, al ser leyes estatales podrían regular condiciones básicas del ejercicio de los derechos. El argumento es especioso y hay que rechazarlo de plano. Para empezar porque la regulación de las condiciones básicas del ejercicio de los derechos requiere una ley estatal general, no de ámbito restringido como es el del estatuto ya que sirve para asegurar la igualdad de todos los españoles en el ejercicio de los derechos y tal finalidad reclama que sea una sola ley la que fije esas condiciones básicas. La imposibilidad se extenderá tanto a los derechos reservados a la ley orgánica - pero ley orgánica general, no estatutaria- como a los que sólo requieren ley ordinaria.

Hay que descartar, pues, que al aprobar las declaraciones estatutarias, el legislador estatuyente ejerza la competencia recogida en el artículo 149.1.1 CE. Está en puridad declarando derechos cuyo ejercicio posterior se verá potencialmente afectado por el desarrollo estatal, ex artículo $81.1 \mathrm{CE}$, y por aquellas leyes estatales que establezcan condiciones básicas para asegurar la igualdad de todos los españoles en su ejercicio. El artículo 149.1.1 CE sólo condiciona la función estatuyente en cuanto ésta no puede desconocerlo o vaciarlo de contenido. El Estado, cualquiera que sea el contenido de los estatutos y, por tanto, con independencia de que estos incorporen o no una tabla de derechos.

Podría objetarse que los estatutos, al declarar derechos, en cierto modo los desarrollan, y que esta función de desarrollo requiere la expresa ley orgánica

57 Tal y como advierte BRAGE, ob. cit., p. 205.

58 Como la plasmada en el artículo 10.13 del Estatuto vasco que atribuye una competencia concreta en relación con ciertas asociaciones. 
de desarrollo y que los estatutos de autonomía, a pesar de ser aprobados, en último término, como leyes orgánicas, agotan un procedimiento distinto donde confluyen las voluntades estatal y autonómica, y son por ello un tipo de fuente distinta. Y si una ley orgánica infringe el artículo 81.1 cuando regula materia no reservada, también un estatuto de autonomía infringiría el artículo 81.1 CE si desarrollase alguno de los derechos reservados a la ley orgánica. Esta línea argumental conduce derechamente a excluir la posibilidad de regulación estatutaria de los derechos fundamentales y libertades públicas. Pero a esta conclusión no es tan sencillo llegar pues los estatutos, en el supuesto de que proclamasen derechos ya reconocidos por la Constitución y en los artículos 15 al 29, es decir, los reservados la ley orgánica, no estarían, en puridad, desarrollándolos, habida cuenta de la interpretación restrictiva que el TC ha dado al término "desarrollo" "59 (desarrollo que siempre quedaría abierto al legislador estatal cuyas leyes vinculan a las CCAA) sino reproduciendo la declaración constitucional y no habría, pues, infracción de la reserva del artículo 81.1 CE. El argumento es sutil, pero inútil porque, aunque aceptáramos la constitucionalidad de las "réplicas" estatutarias de derechos fundamentales y libertades públicas, luego el legislador autonómico carecería de competencia para desarrollarlos.

En definitiva, es lógico y sensato que los nuevos estatutos eviten en general la proclamación de derechos reservados a la ley orgánica porque, en sus ámbitos de aplicación, las CCAA carecen de competencia. ${ }^{60}$ Esta afirmación tiene, sin embargo, sus excepciones ya que los estatutos recogen algunos de estos derechos como los de participación en relación con los poderes públicos autonómicos, el derecho de petición o los derechos educativos. En estos ámbitos las CCAA son competentes ${ }^{61}$ y por eso mismo pueden reconocerse en el estatuto tales derechos pues, como hemos explicado, la reserva del artículo 81.1 CE carece de relevancia competencial y no puede inferirse de ella exclusión de ámbito material alguno para las CCAA. Aun así la legislación autonómica estará sometida al desarrollo estatal, ex artículo $81.1 \mathrm{CE},{ }^{62}$ desplegado mediante el ejercicio de la competencia prevista en el artículo 149.1.1 CE o de otras competencias específicas. En definitiva, el artículo 81.1

59 Acerca del alcance del "desarrollo" de los derechos mediante ley orgánica, cfr. BARCELÓ, ob. cit., pp. 96 y ss. BRAGE, ob. cit., p. 202. BIGLINO, ob. cit., p. 46.

60 Aunque GARCÍA TORRES aprecia desborde competencial en algunos de los derechos declarados en el Estatuto de Cataluña, ob. cit., p. 70.

61 Hace notar VIVER que la completa aplicación de ciertos derechos fundamentales necesita leyes autonómicas, ob. cit. p. 32. En parecido sentido BARCELÓ, apoyándose en jurisprudencia del TC, ob. cit., pp. 96 y ss. y Francisco BALAGUER CALLEJÓN (Coord.) en relación con la declaración de derechos andaluza, El nuevo Estatuto de Andalucía, ob. cit., pp., 26 y 27.

62 Lo que, en mi opinión, no pueden hacer los estatutos es "desarrollar leyes orgánicas siempre que los derechos de que se trate entren dentro de su ámbito competencial", tal y como afirma BIGLINO, ob. cit., p. 48. La situación sería pintoresca porque esas leyes orgánicas de desarrollo podrían cambiar y entonces el estatuto diferiría de ellas. Otra cosa es que los estatutos proclamen, como proclaman, derechos reservados a ley orgánica, pero ello no menoscabaría las competencias estatales y la atribución concretada en el art. 81.1 CE. 
CE tampoco puede oponerse como obstáculo para la declaración estatutaria de derechos.

Otros dos preceptos de la Constitución enmarcan la acción del legislador estatuyente: el artículo 138.2 dispone que: "Las diferencias entre estatutos de las distintas Comunidades Autónomas no podrán implicar, en ningún caso, privilegios económicos o sociales"; y en artículo 139.1 CE que dispone: "Todos los españoles tienen los mismos derechos y obligaciones en cualquier parte del territorio del Estado". Habrá que preguntarse si su proyección en el ordenamiento se ve afectada por las declaraciones estatutarias de derechos, y si esto ocurre, cuál será su alcance a partir de ahora.

El artículo 139.1 CE opera sobre legislador estatuyente y también, claro está, sobre el legislador estatal y sobre los autonómicos. Se trata de un límite al ejercicio de las respectivas competencias, mientras que el artículo 138.2 concierne especialmente al legislador estatal — tanto cuando aprueba estatutos como cuando aprueba el resto de sus normas- pues es él quien puede acordar algún tipo de privilegio al aprobar los estatutos. Así pues, también la declaración estatutaria de derechos debe someterse al análisis desde este precepto, pero sería raro que lo infringiese porque el reconocimiento estatutario de derechos no recogidos en la Constitución, no supondría privilegio alguno sino que se trataría de una diferencia de trato, ${ }^{63}$ producto del pluralismo territorial, además de que los demás estatutos podrían incluir idéntico derecho.

Se ha destacado la residualidad del artículo $138.2 \mathrm{CE},{ }^{64}$ de tal suerte que opera como una cláusula de cierre de la ordenación territorial del Estado ${ }^{65}$ para asegurar la igualdad efectiva y la concreción del principio de solidaridad. ${ }^{66}$ Así pues, el legislador estatuyente deberá tener cuidado de no introducir cláusulas estatutarias que conlleven situaciones prohibidas por el artículo 138.2 CE. Una vez aprobados los estatutos, al Estado le quedan sus competencias para evitar privilegios que menoscaben la solidaridad y la igualdad efectiva con las que el artículo 138.2 CE viene conectado.

¿En qué medida el artículo 139.1 CE condiciona al legislador estatuyente? Del tenor literal del precepto pudiera inferirse que contiene una prohibición tajante de cualquier desigualdad basada en la titularidad de los derechos, pues si todos los españoles han de poseer los mismos derechos en cualquier parte

63 José BAÑO LEÓN considera al art. 138.2 CE una concreción del principio de uniformidad, pero no puede operar como prohibición de toda diferencia, Las autonomias territoriales y el principio de uniformidad de las condiciones de vida, IVAP, Oñate, 1988.

64 Que hacen notar GARCÍA ROCA, "Asimetrías autonómicas y principio constitucional de solidaridad", Revista Vasca de Administración Pública, núm. 47-II (1997), p. 88, PEMÁN, ob. cit., p. 254 y Pablo LUCAS VERDÚ y Pablo LUCAS MURILLO DE LA CUEVA, "Artículo 138", en Oscar ALZAGA,(dir.), Comentarios a la Constitución española de 1978, EDERSA, Madrid, 1999, Tomo X, p. 464.

65 Es lógico por ello que el TC se haya ocupado poco de este precepto, GARCÍA ROCA, ob. cit., p. 73.

66 Conexión con la igualdad sustancial y con la solidaridad que resaltan LUCAS VERDÚ y P. LUCAS MURILLO DE LA CUEVA, ob. cit., p. 462 y GARCÍA ROCA, ob. cit., p. 73. 
del territorio del Estado, ningún estatuto de autonomía podría declararlos aunque extendiera su titularidad a todos los españoles (lo que los nuevos estatutos no hacen porque reservan los derechos estatutarios a los ciudadanos respectivos). Esta estricta y literal interpretación no permitiría tampoco la incidencia autonómica a través de la legislación infraestatutaria, y se devaluaría nuestra descentralización. Como es obvio, la realidad y el entendimiento jurisprudencial ${ }^{67}$ han ido en otro sentido y el artículo $139.1 \mathrm{CE}$ se ha interpretado como una proyección del principio de igualdad que impone la no discriminación entre españoles dentro de cada ordenamiento pero admite que cada uno de estos pueda diferenciarse en la manera de tratar los derechos. $^{68}$ Se desactivaba al artículo $139.1 \mathrm{CE}$ de su carga uniformadora que resultaba incompatible con un Estado compuesto y, en consecuencia, se abrían considerables espacios para que las CCAA incidieran en los derechos, incluidos los reservados a ley orgánica. ${ }^{69}$

De lo anterior se colige que no es el artículo 139.1 CE obstáculo para que el legislador estatuyente declare derechos, ya que lo único que le impide hacer es introducir discriminaciones estatutarias entre españoles, y no lo es el reservar los derechos a los ciudadanos de la CA respectiva, pues estos son los españoles con residencia legal en ella.

Una vez aprobado el estatuto, el artículo 139.1 CE seguirá operando como criterio interpretativo y como límite a la acción legislativa autonómica, pero esta proyección es muy lábil ya que no se han extraído de esta disposición efectos normativos autónomos ${ }^{70}$ sino que siempre ha ido de la mano de la competencia estatal ex artículo 149.1.1 CE, al punto de configurar ambos preceptos la preservación de la igualdad en el Estado autonómico. ${ }^{71}$ Lo verdaderamente importante es la competencia estatal para establecer las condiciones básicas del ejercicio de los derechos y del cumplimiento de los deberes constitucionales, ya que es a través de esta competencia como se hace valer la igualdad de derechos reclamada en el artículo 139.1 CE. Este precepto no es una competencia sino un límite para el Estado y para las $\operatorname{CCAA}^{72} \mathrm{y}$

67 Un estudio completo de la jurisprudencia del TC respecto del artículo $139.1 \mathrm{CE}$ nos lo ofrece CABELLOS, ob. cit., pp. 36 y ss. También BRAGE, ob. cit., pp. 193 y ss.

68 En este sentido LUCAS VERDÚ y P. LUCAS MURILLO DE LA CUEVA, "Artículo 139. Autonomía e igualdad", en ALZAGA (dir.), ob. cit., Tomo X, p. 480, BARCELÓ, ob. cit., p. 127, DÍEZPICAZO, ob. cit., pp. 64 y 65, Ignacio de OTTO PARDO, Estudio ssobre derecho estatal y autonómico, Civitas, Madrid, 1986, pp. 153 y ss.

69 Así lo destacan LUCAS VERDÚ y P. LUCAS MURILLO DE LA CUEVA, “Artículo 139...”, ob. cit., p. 477.

70 Como ha puesto de relieve PEMÁN, ob. cit., pp. 140 y ss.

71 Acción conjunta que aprecia DÍEZ-PICAZO, ob. cit., p. 71. En el mismo sentido, BARCELÓ especifica las funciones que cumple este precepto, a saber: mandato de uniformidad, mandato de homogeneidad mínima y mandato de igualdad de todos los españoles en todo el territorio nacional, ob. cit., pp. 65 y ss.

72 Tal y como sostienen LUCAS VERDÚ y P. LUCAS MURILLO DE LA CUEVA, "Artículo 139...", ob. cit., p. 477. 
un principio general que informa la regla competencial del artículo 149.1.1 CE y orienta su interpretación. ${ }^{73}$ Pero más allá de estas funciones, el precepto resulta ser, en cierto modo, una "duplicación" del artículo 149.1.1 $\mathrm{CE}^{74}$ y no es extraño que se le haya tildado de superfluo. ${ }^{75}$

De lo dicho se desprende que los artículos 81.1, 139.1 y 149.1.1 de la Constitución enmarcan la acción del legislador estatuyente, pero no se infiere de ellos prohibición de declarar derechos en los estatutos. Ahora bien esta declaración estatutaria de derechos no vacía la reserva de ley orgánica ni la competencia reconocida al Estado en el artículo $149.1 .1 \mathrm{CE},{ }^{76}$ inspirada por lo establecido en el artículo 139.1 CE que permanecen intactas porque, al aprobar declaraciones estatutarias, el Estado no desarrolla derechos en el sentido del artículo 81.1 CE ni ejerce su competencia para fijar las condiciones básicas del ejercicio de los derechos y del cumplimiento de los deberes constitucionales.

La actividad estatuyente tiene que situarse principalmente en el artículo 147 CE cuyo apartado primero dispone la función institucional del estatuto en nuestro sistema de fuentes y cuyo apartado segundo enumera sus contenidos mínimos, conformando una reserva relativa ya que los estatutos regulan otras materias a las que la Constitución expresamente se refiere en diversos preceptos. Todas estas materias tienen un marcado carácter organizativo, lo que alimenta la tesis de que hay un contenido constitucionalmente tasado de este tipo de normas, puesto en relación con su fin institucional. Si admitimos esta tesis, entonces no son legítimas las declaraciones estatutarias de derechos por infracción de la reserva estatutaria, y concluiríamos en que sólo la Constitución puede declarar derechos.

Sin embargo, a la vista de la realidad desbordante de nuevos estatutos que declaran derechos, aprobados por casi todos los partidos políticos incluyendo, salvo en el caso catalán, el Partido Popular, cabe preguntarse si es viable la drástica solución de considerar inconstitucional toda declaración estatutaria, aún más cuando algunos estatutos no van a ser objeto de impugnación ante el TC, lo que impedirá su inmediata declaración de inconstitucionalidad. Los acontecimientos parecen, pues, conducirnos a lo que probablemente sea una mutación de los contenidos y funciones de los estatutos que, en todo caso, mantenga la distinción entre función constituyente y función estatuyente. ${ }^{77}$ Habrá que estar atentos a la sentencia del TC que resuelva los recursos de inconstitucionalidad contra el estatuto de Cataluña. La solución de la Cor-

73 Ibid, p. 480.

74 Opinión de CABELLOS, ob. cit., p. 20.

75 Ibid, pp. 36 y ss.

76 GARCÍA ROCA advierte que las declaraciones estatutarias de derechos no pueden menoscabar la reserva de ley orgánica ni la competencia estatal ex art. 149.1.1 CE, “El riesgo...”, ob. cit., p. 101.

77 Tal y como, con argumentos distintos, sostienen GARCÍA ROCA, "El riesgo...", ob. cit., p. 107 y Luis ORTEGA ÁLVAREZ (dir.), La reforma del Estado Autonómico, CEPC, 2005, pp. 18 y ss. 
te Constitucional italiana, ${ }^{78}$ consistente en privar de eficacia normativa a los preceptos de los estatutos regionales que declaran derechos, no parece posible a la luz de los estatutos españoles que los presentan como vinculantes para los poderes públicos, con todos los atributos de los derechos fundamentales.

La construcción argumental que había de emplearse para materializar la mutación, partiría de establecer la conexión entre la declaración de derechos y el ejercicio de las competencias asumidas por la comunidad autónoma respectiva. Los derechos estatutarios vendrían a limitar, orientar e impulsar ese ejercicio. Y su declaración respetaría así la función institucional asignada al estatuto por el artículo 147.1 CE. De la anterior se colige que, a priori, las declaraciones no serían inconstitucionales, ${ }^{79}$ salvo que les faltara la conexión competencial. Así que es posible declarar derechos que tengan esa conexión. Si se declarasen derechos sin competencia en su ámbito normativo, una de dos o sería inconstitucional su declaración o simplemente inútil y superflua porque el legislador autonómico carecería de competencia para regularlos posteriormente, al haber quedado meridianamente claro que las declaraciones estatutarias de derechos no generan competencias nuevas ni alteran el régimen de distribución de las existentes. ${ }^{80}$

Sentado lo anterior, conviene observar que las declaraciones estatutarias pueden incorporar derechos reservados a ley orgánica - y en efecto los declaran- pero sólo es legítima tal declaración si la comunidad autónoma posee competencias en su ámbito de ejercicio. Ocurre con los derechos educativos o los de participación, entre otros. En estos ámbitos la legislación orgánica estatal condicionará el despliegue de tales derechos y su desarrollo mediante ley autonómica, en la medida en la que el Estado sea competente.

Del panorama trazado se colige sin dificultad que el sistema español de declaración de derechos, aun admitiendo la mutación explicada (mutación que rompe con la concepción unitaria ${ }^{81}$ de los derechos que hasta ahora se ha desprendido de nuestra Constitución), no podrá parangonarse con una federalización completa, porque ésta comportaría autonomía constituyente de los entes descentralizados y libertad para declarar sin restricciones los derechos que se deseasen. ${ }^{82}$

Luis María Díez-Picazo, ${ }^{83}$ para quien la reserva material a favor de estatuto impide declaraciones estatutarias de derechos, aporta, además, dos argu-

78 Las sentencias de la Corte constitucional italiana son la 372/2004, acerca del Estatuto de la Región Toscana, 378/2004, sobre el Estatuto de la Región Umbría, y la 379/2004 acerca de la Región Emilia Romagna, todas de 29 de noviembre.

79 Lo que sostiene MUÑOZ MACHADO, aunque para él no serían en realidad derechos fundamentales, "El mito del Estatuto-Constitución", ob. cit., p. 72.

80 Sin embargo, BIGLINO nos pone en guardia contra riesgo de que por esta vía se amplíen las competencias autonómicas, ob. cit., p. 59.

81 Rompimiento contra el que clama Lorenzo MARTÍN RETORTILLO, ob. cit., p. 16.

82 En este sentido se pronuncian PEMÁN, ob. cit., p. 193 y TAJADURA, ob. cit., p. 62.

83 ob. cit., pp. 71 y ss. 
mentos sustantivos: primero, el carácter antidemocrático de las declaraciones que limita, sin título constitucional para ello, al legislador del futuro (se entiende que al legislador autonómico). Este argumento se sostiene porque se parte de la inconstitucionalidad formal de las declaraciones ya que si no se comparte este punto de partida y la opción estatuyente no es inconstitucional, tal opción entra en el margen de discrecionalidad del legislador, con arreglo a un procedimiento de elaboración en el que ha participado el parlamento autonómico que sufrirá las limitaciones a las que el autor se refiere. Si el estatuto puede legítimamente declarar derechos, su vinculación al legislador autonómico es consecuencia natural de su posición cimera en el sistema de fuentes de la comunidad autónoma concernida.

El otro argumento apuntado por Díez-Picazo es ingenioso y se expone con brillantez: la tesis del "legislador esquizofrénico" que aprueba declaraciones contradictorias en diversos estatutos. Sin embargo, la lectura de los estatutos aprobados y de los que están en tramitación ofrece, como veremos más adelante, cierta uniformidad y no se advierten entre ellos graves contradicciones en materia de derechos. Por lo demás, las eventuales diferencias vendrían justificadas por el pluralismo territorial que activan los parlamentos autonómicos aprobando propuestas de reforma que contienen declaraciones de derechos. Convendría, desde luego, que las Cortes Generales fueran coherentes sobre todo porque se lo demanda el artículo 138.2 CE, pero esta coherencia no implica uniformidad, aunque puede exigírsele no contradicción. ${ }^{84}$ Más incongruencias se vislumbran en otros terrenos más peligrosos, como el de la financiación, donde están comprometidas competencias estatales. Es, pues, en el terreno puramente competencial, indiscutible materia estatutaria, en donde se están generando más contradicciones. En materia de derechos, por otra parte, el Estado conserva su facultad de fijar las condiciones básicas del ejercicio de los derechos para asegurar un mínimo común denominador y preservar así la coherencia del sistema de protección de los derechos en España.

\section{PANORAMA DE LOS DERECHOS ESTATUTARIOS}

Las nuevas declaraciones estatutarias son innovadoras y en ocasiones sorprendentes. En ciertos aspectos superan en lo innovador incluso a la Carta de Niza en la que se han inspirado. ${ }^{85}$ Por un lado, recogen derechos subjetivos y, por otro, formulan principios rectores en cada uno de los ámbitos y sectores donde antes se han proclamado derechos. El resultado es que los poderes públicos se hallan constreñidos no sólo por la proclamación misma de

84 De tal suerte que las declaraciones de derechos no presenten "contradicciones materiales" entre ellas, GARCÍA ROCA, "El riesgo...", ob. cit., p. 101.

85 Inspiración que han destacado BALAGUER, La reforma de los Estatutos de Autonomía, ob. cit., pp. 53 y 54, y CARRILLO, ob. cit., pag. 70. 
cada derecho, lo que acaso bastaría, sino asimismo por la formulación de principios que orientan la acción pública en esos ámbitos donde se han proclamado derechos. Alguna propuesta de estatuto (la canaria) opta por recoger sólo principios rectores omitiendo la declaración de derechos. Por lo general, sin embargo, los nuevos estatutos optan por una exuberancia latinoamericana ${ }^{86}$ que si bien es criticada por muchos, ${ }^{87}$ es por otros elogiada. ${ }^{88}$ Se ha apuntado ${ }^{89}$ la inflación de derechos y la parcialidad ideológica de la declaración catalana, crítica que tal vez pudiera extenderse a otras.

Las declaraciones estatutarias difieren entre sí pero, al mismo tiempo, y en lo que toca a su contenido, también presentan bastante semejanzas. Eluden referirse a buena parte de los derechos constitucionales y no sólo a los reservados a ley orgánica. Ni el derecho a la vida y a la integridad ni los derechos a la libertad ideológica y religiosa, ni la libertad personal, al honor, a la intimidad y a la propia imagen, ni el derecho al secreto de las comunicaciones y a la inviolabilidad de domicilio, ni la libertad de circulación y residencia, ni las libertades de expresión y de información, ni el derecho de reunión, ni el de asociación ni el derecho a acceder a cargos públicos (salvo alguna especificación) ni los derechos procesales ni el derecho a la legalidad penal ni la libertad sindical ni el derecho de huelga, ni el derecho de propiedad ni el derecho a contraer matrimonio ni el derecho al trabajo ni la libertad de empresa vienen proclamados en los estatutos, pero sí lo están en la Constitución. Ello no obsta para que algunos estatutos se refieran a ciertos aspectos de estos derechos.

En definitiva, se sigue la pauta de reconocer derechos en cuyo ámbito tienen competencia las respectivas CCAA. Así pues, se centran en los derechos sociales, aunque varíen en la manera de declararlos. Varios de estos derechos ya se preludian en la Constitución, aunque casi siempre sin reconocimiento de derecho subjetivo alguno, sino con la proclamación de principios rectores. Los nuevos estatutos intentan convertir en derechos subjetivos -así los formulan al menos- principios rectores de la Constitución. Por último también hay derechos nuevos, bien que algunos de éstos pudieran acaso inferirse de derechos constitucionales..$^{90}$ En general, se han centrado en los derechos económico sociales, en aquellos de participación política en las propias instituciones y en los que tiene que ver con la respectiva identidad cultural. Este panorama no difiere del que suele caracterizar a las constituciones de los estados federados. ${ }^{91}$

86 Generosidad que resalta FERRERES, ob. cit., pp. 25 y ss. y critica GARCÍA ROCA, para quien se deberían evitar los excesos y reiteraciones, "El riesgo...”, ob. cit., p. 105.

87 Cfr. epígrafe cinco de este trabajo

88 Según BALAGUER, puede anticipar futuras reformas constitucionales, ob. cit., pag. 53.

89 FERRERES, ob. cit., pp. 23 y ss.

90 Nuria GARRIDO distingue dos tipos de derechos: sociales y derechos nuevos, pp. 172 y ss. Sobre los nuevos derechos de los estatutos regionales italianos como el derecho a la paz o los derechos de los animales, cfr. ROSSI, ob. cit., pp. 216 y ss.

91 Tal como pone de relieve CASTELLÁ, ob. cit., p. 25. 
Los derechos sociales son los más numerosos y los que menos polémica $\operatorname{suscitan}^{92}$ por ser las CCAA competentes en su ámbito de ejercicio y por ser los más susceptibles de ampliación..$^{93}$ Bien es cierto que el Estado podrá, invocando el artículo 149.1.1 CE y otros títulos competenciales, fijar estándares mínimos que no podrán rebajar las CCAA. ${ }^{94}$ Algunos estatutos, en especial el catalán, el andaluz y la propuesta castellano manchega (que lleva a la técnica al paroxismo) proclaman derechos de los integrantes de sectores concretos de la población: mujeres, menores, personas mayores, discapacitados; incluso, expresamente en la propuesta castellano manchega, se reconocen derechos de las personas desfavorecidas, de los jóvenes o de las minorías colectivas.

En el Estatuto catalán y, en menor medida en otros, la declaración de derechos de ciertos grupos es una reiteración de la proclamación de derechos en beneficio de todos, lo que no indica buena técnica legislativa, pues no tiene sentido, por ejemplo, proclamar universalmente el derecho a vivir con dignidad (artículo 15 del Estatuto catalán) y luego predicarlo de las mujeres y de las personas mayores. La atención específica a ciertos grupos sociales sólo tiene sentido para reconocer a sus componentes derechos específicos, como el de protección integral en beneficio de los menores (artículo 17 del Estatuto catalán) o el derecho de las mujeres a la protección integral frente a la violencia machista (artículo 16 del Estatuto andaluz).

También utilizan los estatutos la técnica, ya antigua, de enunciar ámbitos concretos para reconocer derechos que en tales ámbito se ejercen; así los ámbitos de la familia, la educación, de la salud, cultural, servicios sociales, trabajo, vivienda, consumidores o medio ambiente. En todos ellos, con mayor o menor intensidad, inciden las declaraciones estatutarias para reconocer derechos más pormenorizadamente que la Constitución o convertir principios constitucionales en derechos estatutarios, algunos de los cuales ya han sido regulados por leyes estatales.

Los nuevos estatutos recalcan la promoción de la igualdad entre hombre y mujer en todos los ámbitos, con preferencia en el laboral y en el de participación política. Precisamente en este último, los estatutos pormenorizan y amplían, respecto de las instituciones autonómicas, derechos constitucionales en la materia,. Y en relación con la administración autonómica los nuevos estatutos proclaman derechos a la buena administración, siguiendo la estela del artículo 39 de la Carta de Niza. Aprovechando la oportunidad, declaran también el derecho a la autodeterminación informativa que la jurisprudencia del TC ha inferido del artículo 18.4 CE.

En los artículos 15.2 del Estatuto catalán y 12.1 del nuevo Estatuto para Aragón se proclama el derecho a vivir con dignidad, seguridad y autonomía, libres de explotación, de malos tratos y de todo tipo de discriminación; y el

92 Aunque algunos derechos puedan suscitarla como el derecho al agua proclamado en los artículos 17 del Estatuto valenciano y 19 del aragonés.

93 Posibilidad de ampliación que destaca ROSSI, ob. cit., p. 210.

94 Como recuerda MUÑOZ MACHADO, ob. cit., p. 77. 
derecho al libre desarrollo de la personalidad y capacidad personal. Estos dos genéricos derechos son el pórtico de ambas declaraciones y todos los demás derechos sirven a su efectividad. Debe entenderse, pues, que sólo cuando el resto de los derechos estatutarios se satisfaga podrán ejercerse en plenitud éstos dos derechos esenciales a vivir con dignidad y al libre desarrollo de la personalidad.

Su esencialidad no impide que sea muy problemático identificar las posiciones iusfundamentales comprendidas en uno y otro derecho ¿A qué se tiene en puridad derecho cuando se invocan? ¿Qué se puede exigir con su invocación? No parece sencilla la tarea que aguarda a los legisladores autonómicos concernidos cuando tengan que concretar los contenidos de ambos derechos. Más bien ocurre que la vida digna y el libre desarrollo de la personalidad resultan de la satisfacción de las concretas libertades y derechos, en especial los sociales, que la Constitución española y los estatutos reconocen, y no tanto de la exigibilidad directa que pueda reclamarse desde estos dos derechos.

Lo anterior es lo que parece acontecer en la Constitución española en cuyo artículo 10.1 se mencionan "la dignidad de la persona, los derechos inviolables que le son inherentes, el libre desarrollo de la personalidad son el fundamento del orden jurídico y de la paz social". En lugar de dotar a la dignidad y al libre desarrollo de la personalidad de un estatuto de derechos subjetivos se los construye como principios axilógicos del ordenamiento, conectándolos con el ejercicio de los derechos específicamente reconocidos y que son fundamentales por ser inherentes a la dignidad.

Es en este punto, en definitiva, donde los Estatutos catalán y la propuesta aragonesa más se apartan de la literalidad de la Constitución al optar por la senda subjetivista. Aunque se mantenga la coherencia material entre los artículos estatutarios citados y el artículo 10.1 de la Constitución, la técnica empleada es diferente, dando así lugar a que los ciudadanos catalanes puedan invocar en su Comunidad el derecho a vivir con dignidad y el derecho al libre desarrollo de la personalidad que no puede invocar el resto de los ciudadanos españoles.

Además podría discutirse si éstos dos derechos proclamados no invaden terreno vedado, por cuanto que las respectivas comunidades carecen de competencias para su desarrollo. Pero como tampoco la Constitución, aunque se refiere, en su artículo 10.1, a los bienes jurídicos por tales derechos tutelados, tampoco los reconoce; tales derechos se hallan así en un terreno de nadie.

También ha suscitado polémica la proclamación, en los artículos 20.1 del Estatuto catalán y 20.1 del Estatuto andaluz, del derecho a vivir dignamente el proceso de la propia muerte, acompañado del derecho a formalizar testamento vital (artículos 20.2 del Estatuto catalán y 20.2 del Estatuto andaluz). Para los críticos, vienen a reconocer de manera encubierta la eutanasia. En todo caso el Estado retiene la competencia para fijar las condiciones básicas y desarrollar el derecho a la vida y el derecho la protección de la salud, pero las CCAA catalana y andaluza podrán incidir en su ámbito ejerciendo sus competencias en materia sanitaria. 
Una de las novedades de los nuevos estatutos que ha pasado casi inadvertida $^{95}$ es la elevación a rango estatutario de los derechos reconocidos en los tratados sucritos por España e incluso de los derechos comunitarios. ${ }^{96}$ La fórmula literal empleada suele ser "son titulares", "gozan de los derechos", o simplemente "Son." Pero todas ellas convierten sin más tales derechos en derechos estatutarios, sin que quede claro si gozarán de las garantías correspondientes, aunque más bien parece que no. ¿De qué sirve en realidad esta ampliación del ámbito de los derechos de los que gozan los ciudadanos de las CCAA respectivas? Parece una mala técnica legislativa desbordar la apertura prevista en el artículo $10.2 \mathrm{CE}$ que no constitucionaliza los tratados y que se limita a exigir la interpretación de nuestro derecho interno a la luz de tales declaraciones internacionales, incluyendo, entre éstas, el derecho comunitario, así como la interpretación dada por los tribunales internacionales y comunitarios.

Un aspecto central del estatuto catalán es su deseo evidente de normalizar el uso de la lengua catalana, ${ }^{97}$ declarada lengua propia en el artículo 6.1. Su uso habrá de ser preferente y convertirse en lengua vehicular de la enseñanza. Todos tienen el derecho y el deber de conocer tanto el catalán como el castellano (artículo 6.2); el uso de una u otra lengua no puede ser causa de discriminación (artículos 6.2 y 32). A mayor abundamiento se reconoce (artículo 36.1) el derecho de opción lingüística que no se proyecta, sin embargo, en la enseñanza, puesto que en todos los colegios financiados con fondos públicos la enseñanza se desarrollará en catalán, enseñándose el castellano como una lengua más.

No se reconoce, pues, el derecho de opción lingüística en el ámbito educativo como sucede, por ejemplo, en el País Vasco. Este derecho puede ejercerse frente a cualquier poder público, autonómico o estatal que opere en Cataluña, salvo frente a la administración educativa, a la que no se impone la obligación de ofrecer enseñanzas en castellano, mientras que cualquier otro poder público (autonómico o estatal) debe estar preparado para atender en catalán o en español según la opción del ciudadano. Bien es cierto que se declara el deber de conocer la lengua estatal (artículos 6.1 y 35.2) pero al tiempo que igual deber existe de conocer el catalán, y puesto que la enseñanza será básicamente en catalán, lengua propia, no hay duda de que se posterga al castellano para potenciar el uso habitual de catalán, de tal suerte que el español queda como segunda lengua, es oficial pero no la propia de Cataluña. Como es sabido, esta regulación estatutaria no supone sino una elevación de rango normativo de lo ya establecido en la legislación catalana. Nada hay que objetar, por lo demás, a la regulación estatutaria del uso de la lengua propia, que también acometen los estatutos de CCAA con lengua vernácula, pues su

95 Aunque la hayan sagazmente advertido BIGLINO, ob. cit., p. 54 y DÍEZ-PICAZO, ob. cit., p. 72 .

96 Arts. 15.1 del Estatuto catalán, 9.1 del andaluz, 14 del balear, 8 del valenciano, 8.1 de la propuesta de reforma castellano leonesa y 7.1 de la castellano-manchega.

97 Sobre la cuestión, cfr. BIGLINO, ob. cit., p. 60. 
regulación entra en la reserva constitucional de estatuto, ex artículo $3.2 \mathrm{CE}$. Las dudas se suscitan a propósito del contenido de la regulación estatutaria catalana.

\section{IV. ¿REPETIR, CONCRETAR O SUPLIR?}

El modelo clásico federal presenta una dualidad de declaraciones, federal y estatales, que implica la duplicidad. Cada declaración vinculaba originalmente sólo a los poderes territoriales respectivos, así la declaración federal, contenida en las nueve primeras enmiendas de la Constitución de los Estados Unidos, era oponible, en un primer momento, sólo frente a las autoridades federales, mientras que las declaraciones estatales sólo lo eran frente a los poderes estatales. Cada círculo de poder territorial quedaba, pues, vinculado a una sola declaración de derechos. Además, como se recordará, originalmente la protección de los derechos se consideró materia privativa de los Estados, y sólo después, para precaverse contra los posibles abusos de la Federación, se introduce la declaración federal. ${ }^{88}$ Sólo mucho más tarde, tras la guerra civil y la introducción de las enmiendas XII, XIII y XIV los derechos federales comienzan a proyectarse sobre la acción de los Estados, aunque la proyección generalizada sólo tuvo lugar en pleno siglo xx con el respaldo del Tribunal Supremo presidido por Warren. ${ }^{99}$

Separados de este modo los ámbitos federal y estatal, los derechos tenían que recogerse plenamente en las respectivas declaraciones, ya que las omisiones en una declaración no venían paliadas por lo establecido en otras. Sólo cuando la declaración federal pasó a vincular no sólo a la federación sino también a los Estados, éstos podrían omitir cualquier declaración propia, hacer expresamente suyos los derechos federales o disponer una declaración que no contuviera todos los derechos imaginables. ${ }^{100}$

El proceso de extensión de los derechos federales a los Estados que registra la experiencia histórica estadounidense parece, de una u otra suerte, estarse viviendo ahora en el proceso de integración europea. En primer lugar, la reticencia a que el Derecho comunitario se ocupase de los derechos; en segundo lugar, protección jurisprudencial de los derechos para proteger la libertad frente a la acción puramente comunitaria; en tercer lugar, una declaración, la Carta de Niza, con una lista exhaustiva de derechos que vincula a las instituciones comunitarias así como a los Estados miembros, pero sólo cuando apliquen el Derecho comunitario.

Una vez explicada la justificación originaría de la duplicidad de declaraciones de derechos en el Estado federal hay que sumar la autonomía consti-

98 Cfr. TARR, ob. cit., pp. 40 y ss.

99 Ibid., pp. 56 y ss.

100 Variedad que sintetiza CASTELLÁ, ob. cit., pp. 12 y ss. 
tucional de los Estados partes que, en uso de su poder constituyente, pueden o no incluir una declaración completa de derechos que recoja todos los indispensables, propios e inexcusables del Estado constitucional, o que los omita cuando considera que la declaración federal es suficiente, o que se limite a completar la carta federal con derechos nuevos o con ampliaciones de los federales. En definitiva, la duplicidad completa en los contenidos sólo era indispensable cuando la declaración federal no aseguraba los derechos frente a los Estados.

Así las cosas, el panorama que ofrecen en la actualidad los Estados federales es muy variado, pero predomina la duplicidad, a pesar de que las declaraciones federales vinculan también a los Estados. Y acaso por la facilidad relativa con la que puede reformarse las constituciones estatales, éstas se renuevan con más frecuencia y experimentan más.

En el contexto español no ha habido, hasta la aprobación del Estatuto catalán, duplicidad territorial de declaraciones de derechos. No era claro, no lo es aún porque no se ha debatido suficientemente, si el ejercicio del derecho a la autonomía, y más en concreto la acción estatuyente, podía comprender la declaración de derechos. Este trabajo es una modesta aportación a ese debate que ya no versa sobre una hipótesis sino sobre la realidad de nuevos estatutos que declaran derechos. Lo que sí quedó claro pronto fue que la estructura territorial del Estado afecta a los derechos fundamentales porque las legislaciones autonómicas podrían incidir en ellos, respetando las competencias estatales. En el epígrafe dos de este trabajo nos hemos referido a la legitimidad constitucional de las declaraciones estatutarias. Según lo dicho entonces, los estatutos de autonomía podrían contener derechos siempre y cuando ello no impida el ejercicio por parte del Estado de sus propias competencias, en particular de la recogida en el artículo 149.1.1 CE y en otras propias del Estado que, como sucede con las Comunidades autónomas, permitan incidir en derechos específicos (por ejemplo los de propiedad, los educativos, los sanitarios, etcétera). Potencialmente, pues, las Comunidades podrían reproducir derechos proclamados en la Constitución, completarlos con contenidos nuevos o declarar nuevos derechos.

Varios derechos constitucionales se reproducen estatutariamente, ${ }^{101}$ en especial derechos sociales de prestación para cuya satisfacción están obligadas las Comunidades que gozan de la competencia en la materia. Es el caso paradigmático de la educación o de la sanidad. Bien es verdad que incluso en estos casos, la declaración estatutaria y la legislación que la desarrolle están vinculadas al ejercicio que el Estado haga de sus propias competencias. Formalmente el legislador autonómico se halla vinculado a los derechos estatutarios, pero también, claro está, a la declaración constitucional y a la legislación estatal correspondiente porque la declaración estatutaria de derechos no

101 Hecho advertido por BIGLINO que lo caracteriza como una reiteración o solapamiento, ob. cit., pp. 50 y ss. y que desaconseja GARCÍA ROCA, "El riesgo...”, ob. cit., p. 105. 
condiciona, como ya hemos apuntado, el despliegue de las competencias estatales para regular los derechos. En contraste, en otros ámbitos donde la competencia estatal sea menos amplia o no exista, la incidencia de las leyes estatales disminuirá y el legislador autonómico quedará vinculado casi únicamente a la declaración estatutaria.

Parece, pues, justificada la declaración de derechos sociales cuya prestación corresponde en exclusiva las CCAA. Pero los estatutos contienen otros derechos cuya declaración es redundante pues ya los proclama la Constitución, ${ }^{102}$ por ejemplo el derecho de participación política o el de no discriminación. Se trata de especificaciones o concreciones de sus "réplicas" constitucionales, ${ }^{103}$ que se declaran en relación con las instituciones autonómicas, desglosándose y enriqueciendo su contenido. También hallamos muchos derechos nuevos ${ }^{104}$ aunque algunos de ellos podrían integrarse en algunos de los consagrados en la Constitución, lo que ocasionará problemas interpretativos en el futuro. Respecto de los nuevos habría que preguntarse si no sería mejor evitar esa congelación de rango para mantener abiertas las posibilidades del legislador autonómico del futuro. ${ }^{105}$

Por razones de puro sentido común los estatutos deberían obviar declarar derechos ya constitucionalizados en cuyo ámbito la Comunidad carezca de competencia. ${ }^{106}$ Por regla general este proceder es el que se está siguiendo, aunque hay excepciones. Si esta declaración se produjera, duplicándose derechos en cuyo ámbito la Comunidad carece de competencia, no resulta nada bueno porque crea confusión, en la medida en la que los términos estatutarios no coincidan con los constitucionales. ¿Para qué serviría entonces un derecho estatutario para cuyo desarrollo la Comunidad carece de competencia? A mi entender estas proclamaciones estatutarias operarían como simples principios informadores de la legislación autonómica que a lo sumo podría hacerse valer a través del control previo sobre proyectos y proposiciones de ley que prevé, por ejemplo, en beneficio del Consejo de Garantías Estatutarias, el artículo 38 del Estatuto catalán.

Al margen de las consideraciones técnico jurídicas juegan factores simbólicos que explican el afán de declarar derechos en los nuevos estatutos; es indudable el interés, ya explicado más atrás, por hacer que los estatutos se parezcan a una constitución. Es por lo anterior por lo que algunas declaraciones estatutarias han tratado de llegar tan lejos.

102 Por eso mismo SÁNCHEZ PÉREZ aconseja no declarar estos derechos, ob. cit., p. 68.

103 Así las explica CARRILLO, ob. cit., p. 70.

104 A los que se refieren, ente otros, CARRILLO, ob. cit., p. 70 y VIVER, ob. cit., p. 32. Y refiriéndose a las experiencias federales en general, CASTELLÁ, ob. cit., pp. 24 y ss.

105 Como advierte FERRERES, ob. cit., p. En parecido sentido SÁNCHEZ PÉREZ, ob. cit., p. 66.

106 Incluso para SÁNCHEZ PÉREZ se debería evitar la reiteración aunque se tenga competencia, ob. cit., p. 68. 


\section{V. ¿SON DERECHOS FUNDAMENTALES?}

En un estado federal no hay duda de que los derechos proclamados en las constituciones estatales son derechos constitucionales y en este sentido comparten naturaleza con los derechos proclamados en la constitución federal y puede hablarse, por tanto, de derechos fundamentales estatales. En la nueva situación española los derechos de las declaraciones estatutarias no son obviamente constitucionales, pues los estatutos de autonomía se aprueban como leyes orgánicas y carecen de rango formalmente constitucional. Podríamos calificarlos - y esta sería una nueva categoría dogmática- como "derechos estatutarios", atendiendo a la norma donde se proclaman.

Ahora bien, los estatutos, como es bien sabido, forman parte del bloque de constitucionalidad y, en consecuencia, del canon de enjuiciamiento del TC a la hora de determinar las competencias controvertidas. Si esto es así, podría pensarse que los derechos estatutarios operarían también como normas constitucionales secundarias y materialmente serían derechos constitucionales. Este argumento, sin embargo, no puede, a mi juicio, compartirse porque los derechos estatutarios no crean competencias nuevas y no modifican el reparto de poder político entre el Estado y la comunidad respectiva, así que las normas de derechos estatutarios no fungen en el ordenamiento jurídico global cómo operan las normas estatutarias atributivas de competencias. En definitiva, aunque los derechos son materia típicamente constitucional, los estatutarios ni gozan formalmente de ese carácter ni materialmente forma parte de las normas constitucionales secundarias; no son normas constitucionales del todo como si lo son las que atribuyen competencias; éstas completan las normas formalmente constitucionales y reparten verticalmente el poder político, en cambio los derechos estatutarios no vinculan, en principio, a los poderes públicos estatales, salvo a los tribunales, ni su declaración menoscaba las competencias del Estado.

Descartada su condición de derechos constitucionales, tanto desde la perspectiva formal como desde la material, corresponde preguntarse si los derechos estatutarios son derechos fundamentales. Si la fundamentalidad del derecho depende de su inclusión en la Constitución, entonces no son fundamentales. Sin embargo, si la fundamentalidad depende de su conexión con la dignidad de la persona y con la fuerza vinculante frente a los poderes públicos, incluyendo al legislador, entonces los derechos estatutarios, tal y como se recogen en al menos varios de los nuevos estatutos, aspiran a ser considerados fundamentales, en la medida en la que proclaman esa fuerza vinculante. ${ }^{107}$ La pretensión evidente de estas declaraciones es la de proclamar derechos fundamentales en el ámbito autonómico que, al no poder encauzarse a través de un proceso constituyente propio, se plasman en el estatuto, refrendado en último término, allí donde sea preciso, por el cuerpo electoral.

107 Como advierte DÍEZ-PICAZO, ob. cit., p. 69 y se desprende de los arts. 37.1 del Estatuto catalán, 38 del andaluz y 17.1 de la propuesta de reforma para Castilla y León. 
Habrá que ventilar doctrinal y jurisprudencialmente si los derechos estatutarios son fundamentales, como pretenden configurarlos algunos de los nuevos estatutos. Que se presentan como verdaderos derechos y no como meros principios es innegable ya que aspiran a proyectarse en el ordenamiento autonómico de forma similar a como operan los derechos constitucionales. Pero, como es obvio poseen un ámbito circunscrito a la CA respectiva. Por eso conviene teorizar sobre esta nueva categoría dogmática que hemos denominado "derechos estatutarios", a partir de su ubicación, y reservar acaso la categoría de derechos fundamentales para los reconocidos en la Constitución.

La fuerza vinculante de los derechos fundamentales descansa, según se ha venido considerando, sobre su aplicabilidad directa que alcanzaría no sólo al legislador sino al resto de los poderes públicos, incluidos los tribunales. ${ }^{108}$ Todos estos atributos se tratan de proyectar en los derechos estatutarios, así que no es posible, a mi juicio, negar su naturaleza de verdaderos derechos ${ }^{109}$ para rebajar su eficacia normativa y reducirla a la de servir como meras normas programáticas. ${ }^{110}$

Sin embargo, una buena parte de los derechos estatutarios son de carácter social y prestacional ${ }^{111}$ y su concreción necesariamente pasa por la intermediación del legislador. ${ }^{112}$ No es extraño por consiguiente que la totalidad de los estatutos reclamen del legislador que los desarrolle, bien individualmente (artículo 38 del Estatuto andaluz o artículo 17.2 de la propuesta de Estatuto para Castilla y León), bien mediante una carta de derechos autonómicos que ofrezca una regulación conjunta (artículo 37.2 del Estatuto de Cataluña). ${ }^{113}$ La vinculación para la administración, que permitiría la posible invocación por los ciudadanos, dependerá, en definitiva, de lo previsto en la legislación de desarrollo. Estaríamos entonces, a lo sumo, ante derechos con la estructura de los derechos sociales ${ }^{114}$ que, al ser distinta de la propia de los derechos clásicos de libertad, demanda

108 Cfr. Javier JIMÉNEZ CAMPO, Derechos fundamentales. Concepto y garantías, Trotta, Madrid, 1999, en especial pp. 17 y ss.

109 Como hace MUÑOZ MACHADO, "El mito...", ob. cit., p. 75.

110 Y aun a la de meras orientaciones políticas, en la línea de la solución ofrecida por la Corte Constitucional italiana, tras controlar las declaraciones de los nuevos estatutos regionales (sentencias 372, 378 y 379 de 2004), ROSSI, ob. cit., pp. 277 y ss.

111 Lo que permite a BIGLINO negar su carácter de derechos subjetivos para reducirlos a declaraciones programáticas que diluyen la diferencia entre tales derechos y los principios rectores que a menudo también proclaman los nuevos estatutos, ob. cit., pp. 47 y ss. FERRERES se inclina por la misma tesis e añade que además son superfluos, ob. cit., p. 30. Pero este argumento se podría emplear para descalificar derechos proclamados en la Constitución, en la línea de la mayor parte de la doctrina alemana, HARTWIG, ob. cit., p. 152.

112 Por eso GARCÍA TORRES distingue entre derechos estatutarios inmediatos y derechos estatutarios mediatos, que necesitan desarrollo legislativo, ob. cit., p. 65.

113 Creando así un tipo de norma de desarrollo de los derechos estatutarios que GARCÍA TORRES, en referencia al Estatuto catalán, denomina "leyes orgánicas catalanas", ob. cit., p. 65.

114 Sobre la naturaleza y estructura de los derechos sociales cfr. las atinadas observaciones de Ernst BÖCKENFÖRDE, Escritos sobre derechos fundamentales, Nomos Verlagsgesellschaft, Baden-Baden, 1993, pp. 63 y ss. y de Robert ALEXY, Teoria de los derechos fundamentales, CEC, Madrid, 1997, pp. 419 y ss. 
concreción legislativa; ésta podrá ser más o menos beneficiosa para los ciudadanos según la calidad de las prestaciones previstas. Lo propio de los nuevos estatutos de autonomía es que cierran el margen del legislador al concretar ya, en buena medida, qué prestaciones deben recogerse en la ley.

Los tres estatutos mencionados (catalán, andaluz y castellano leonés) más el aragonés (artículo 6.2) disponen, como hemos visto, esa vinculación de los poderes públicos autonómicos a los derechos proclamados, mientras que el Estatuto valenciano y el balear no la establecen. El Estatuto de Valencia (artículo 8.2), el balear (artículo 13.2) y la propuesta castellano manchega (artículo 7.1) declaran la vinculación de los poderes públicos a los derechos proclamados en la Constitución, el Derecho comunitario y los tratados internacionales suscritos por España, pero no a los reconocidos en el propio Estatuto de autonomía. Parece tratarse de un descuido sorprendente pero de él no cabe colegir que el legislador autonómico quede desvinculado de los derechos estatutarios. Lo mismo puede decirse de la propuesta aragonesa que expresamente no dispone la vinculación de los poderes autonómicos ni a los derechos estatutarios ni a ninguna otra declaración, constitucional o internacional.

Si los derechos estatutarios vinculan a todos los poderes públicos, incluido el legislador, éste ha de respetar el "contenido esencial" de los derechos proclamados. Pero los estatutos que expresamente declaran esa fuerza vinculante, no mencionan tal contenido esencial. Sólo el artículo 38 del Estatuto andaluz dispone que los poderes públicos deberán respetar el "contenido" de los derechos. Esta casi general omisión no tiene, a mi parecer, relevancia porque es obvio que existe un contenido de los derechos estatutariamente declarado, muy amplio por lo demás, al que el legislador autonómico debe atenerse. Al referirme a las garantías de los derechos estatutarios, en el epígrafe ocho de este trabajo, volveré sobre la cuestión.

Para redondear la pretendida fundamentalidad de los derechos estatutarios algunos estatutos (artículo 37.1 del Estatuto de Cataluña, art. 38 del andaluz y art.17 de la propuesta de reforma para Castilla y León) establecen su vinculación también a los particulares si la naturaleza del derecho así lo consiente. Por primera vez en España se introduce normativamente la drittwikung o eficacia entre particulares de los derechos. Lo que tradicionalmente ha sido una creación jurisprudencial adquiere, por primera vez en España, dimensión normativa y acredita el componente innovador y casi experimental de las declaraciones estatutarias. Sin embargo, dado el carácter prestacional de la mayor parte de los derechos estatutarios, no serán muchos los casos en los que puedan invocarse frente a otros particulares. Sí podrá hacerse, por ejemplo, en los casos relativos a la igualdad entre hombres y mujeres o en el supuesto previsto en el Estatuto de Cataluña (artículo 32) de ejercicio del derecho de opción lingüística que potencialmente genera, tal y como el propio estatuto dispone, obligaciones para los particulares.

En la línea de incorporar reglas interpretativas y jurisprudenciales a la norma, reglas que sirven a la fundamentalidad del los derechos, los artículos 37.1 del Estatuto catalán, 38 del andaluz y 17.1 de la propuesta de reforma para 
Castilla y León formulan el principio de interpretación más favorable a la plena efectividad de los derechos de toda la legislación. La obligación de interpretar (y aplicar añade el precepto catalán) la legislación autonómica en el sentido más favorable para esa plena efectividad se dirige, claro está, a los poderes públicos autonómicos, pero parece que también a los tribunales; y aquí tropezamos con un problema: la administración de justicia es en España estatal, sólo hay un poder judicial, a pesar de que su planta se adapte al mapa autonómico. Ello, no obstante, debe entenderse que los tribunales interpretarán y aplicarán la legislación autonómica según el criterio enunciado.

Cabría preguntarse si el criterio interpretativo favor libertatis (en favor de los derechos estatutarios) al constreñir a los tribunales en la comunidad, los obligará también cuando apliquen el derecho estatal o sólo cuando apliquen el derecho autonómico. La cuestión no es meramente académica y tiene su importancia. Podría responderse que como el estatuto es ley orgánica, aprobada por el parlamento estatal, los órganos judiciales que operan en su ámbito de vigencia están sujetos a todas sus cláusulas, incluyendo ésta relativa a su labor interpretativa. La otra respuesta, más ajustada a un Estado compuesto, acotaría el empleo de la citada regla a la interpretación del derecho catalán, mientras que el derecho estatal habría de aplicarse según los criterios de interpretación fijados por el Tribunal Constitucional o por el Tribunal Supremo que incluirían la obligación de interpretar la legislación de la manera más favorable para los derechos constitucionales, obligación que habrán de entenderse vigente cuando se interpreta el derecho autonómico; este habría de interpretarse de la manera más favorable a los derechos estatutarios pero también a favor de los derechos constitucionales.

\section{SUJETOS ACTIVOS Y PASIVOS DE LOS DERECHOS ESTATUTARIOS}

\section{A) Sujetos activos}

No es fácil determinar la titularidad, tanto activa como pasiva, de los derechos estatutarios. En primer lugar porque los propios estatutos no agotan la regulación pertinente que, por lo además, no está en su mano hacerlo ya que el disfrute de los derechos estatutarios, titularidad activa, y la determinación de los vinculados por ellos, titularidad pasiva, también se halla en manos del Derecho comunitario europeo y del Derecho estatal. A éstas hay que añadir ahora las prescripciones estatutarias y, por remisión de éstas, las leyes autonómicas. El panorama es, pues, muy complejo y sin ánimo de ser exhaustivos, vamos a analizar en estas páginas cómo regulan la materia los estatutos recién aprobados y las propuestas de reforma en curso, sin entrar en el análisis pormenorizado de la legislación comunitaria y estatal que nos llevaría, por otro lado, a ocuparnos de la situación de cada derecho en particular. 
En todos los antiguos estatutos se vino a regular la condición de ciudadano de cada comunidad autónoma haciéndola depender de la calidad de ciudadano español que tuviera la vecindad administrativa, residencia, en el respectivo territorio autonómico. Esta condición no llevaba aparejada titularidad de derechos estatutarios, que no existían, pero sí implicaba disfrutar de ciertas posiciones jurídicas individuales, así como de ciertas obligaciones, que el ordenamiento autonómico pudiera introducir. Ahora, con el reconocimiento de derechos en los nuevos estatutos, la condición de ciudadano de la respectiva comunidad lleva aparejada la titularidad de tales derechos, derechos de los que no son titulares el resto de los ciudadanos españoles que no residan en esa concreta comunidad.

A la vista de la anterior, la primera objeción que cabe plantearse es si esta situación conculca el artículo 139.1 CE que dispone, como ya sabemos, que: "Todos los españoles tienen los mismos derechos y obligaciones en cualquier parte del territorio del Estadon. Indudablemente la disparidad y pluralidad de declaraciones estatutarias no conculca la cláusula constitucional citada, como ya explicamos más atrás, porque cualquier ciudadano español, ejerciendo su derecho de libre elección de residencia, puede cambiar su vecindad y adquirirla en otra comunidad; en este caso obtendrá automáticamente la condición de ciudadano en la comunidad donde pasa a residir. Lo dicho tiene perfecta lógica si hablamos de derechos prestacionales satisfechos por la Comunidad o de derechos de participación política en las instituciones autonómicas. Y como es estos ámbitos donde se han desplegado las declaraciones estatutarias, es decir, en materias de competencia autonómica, encajan bien en el sistema global de protección de los derechos. Pueden plantearse, empero, algunos problemas que afectan al ejercicio de ciertos derechos prestacionales y otros no prestacionales por los no residentes. Respecto de los prestacionales piénsese por ejemplo en los sanitarios, tan prolijamente tratados en los estatutos ¿Tendría, por ejemplo, el ciudadano español no residente, en la Comunidad donde se encuentra eventualmente, derecho a acudir a la sanidad pública de esa Comunidad si por una emergencia la necesitara? La respuesta es afirmativa, pero en puridad se ejercería el derecho constitucional a la atención sanitaria, desarrollado por la legislación estatal y no derechos sanitarios autonómicos, salvo que la legislación autonómica de desarrollo, previera esa atención también para los no residentes. En la medida, pues, en la que la legislación básica sanitaria fuera aplicable, la sanidad autonómica estaría obligada a atender al enfermo no residente.

Caso distinto plantea al aquellos derechos estatutarios que por su naturaleza no son prestacionales. Véase por ejemplo el derecho a vivir con dignidad y otros de naturaleza similar reconocidos en el artículo 15 del Estatuto catalán. Se trata de un derecho universal a que no podría negarse a nadie con independencia de la residencia. Y esto ocurriría con cualquier derecho constitucional que tuviera replica en un estatuto pero en cuyo ámbito la Comunidad careciera de competencia. Para estos últimos, como no habría legislación autonómica, la normativa aplicable sería la estatal que, obvio es decirlo, 
vincula a la Comunidad. Han hecho bien los estatutos en omitir la declaración de estos derechos y cuando lo han hecho - con fórmulas más o menos distantes de la Constitución- no podrán negar el ejercicio del derecho a los no residentes. Acaso por ello los propios estatutos no utilizan siempre la fórmula "los ciudadanos" para reherirse a los titulares de todos los derechos sino otras más vagas que de un modo u otro abren la puerta al ejercicio de derechos estatutarios por parte de españoles no residentes o de residentes no españoles. ${ }^{115}$

Son interesantes las cláusulas estatutarias de extensión de la titularidad activa de los derechos proclamados. Estos preceptos son de diferentes tipos, el primero de ellos, el más genérico, abre la puerta a la extensión de los derechos reconocidos a otras personas en los términos que establezcan las leyes. Es la fórmula aplicada por el artículo 15.3 del Estatuto catalán y por el artículo 11.2 del Estatuto de Aragón. Dejan completa libertad al legislador autonómico para llevar a cabo la extensión de la titularidad activa de los derechos, dándole cobertura para ello. En contraste, allí donde nada prevé el estatuto la extensión carece de cobertura expresa.

Mayor apertura presenta el artículo 3.5 del Estatuto valenciano, tras su reforma. Se establece que: "Los ciudadanos de la Unión Europea residentes en la Comunidad Valenciana que no tenga la nacionalidad española gozarán en la misma de los derechos y estarán sujetos a las obligaciones propias de los valencianos, con las excepciones que establezcan, en su caso, la Constitución o las leyes del Estado". En idénticos términos se expresa el art. 3.3 de la propuesta de nuevo estatuto para Castilla La Mancha.

Con esta cláusula tiene lugar una asimilación completa, desde la perspectiva del ordenamiento valenciano, entre ciudadanos españoles y comunitarios residentes en la Comunidad Valenciana, sin más excepciones que las que puedan inferirse del Derecho estatal. La ausencia de un precepto similar en el Estatuto catalán o en otros que vendrán no significa que los ciudadanos comunitarios, residentes en Cataluña o en otras comunidades autónomas carezcan de los derechos que, en el respectivo estatuto, se reconocen expresamente a los ciudadanos españoles en ella residentes, pues se infiere del Derecho comunitario la igualdad de derechos, con las excepciones relativas al derecho de participación. En definitiva, los ciudadanos comunitarios que residan en España gozan, en principio, de los derechos proclamados en los nuevos estatutos de autonomía cuando residan en la respectiva comunidad.

La cláusula más generosa de cuantas se recogen en los nuevos estatutos está contemplada en el artículo 12 del nuevo Estatuto de Andalucía. ${ }^{116}$ En ella se dispone que:

115 Aspecto que observa SÁNCHEZ PÉREZ, en relación con el Estatuto valenciano, ob. cit., p. 67.

116 Sobre el particular, cfr. BALAGUER CALLEJÓN (Coord.), que destaca la generosidad en la extensión del goce de los derechos, El nuevo Estatuto de Andalucía, ob. cit., pp. 34 y 35 
"Los destinatarios de las políticas públicas y los titulares de los derechos y deberes contenidos en este título son todas las personas con vecindad administrativa en Andalucía sin perjuicio de lo establecido para el derecho de participación en los asuntos públicos en el artículo 30 y de acuerdo con las leyes reguladoras de los Derechos Fundamentales y Libertades Públicas".

Con la salvedad de los derechos de participación de los que más adelante nos ocuparemos, el citado precepto andaluz borra la distinción entre ciudadanos españoles y asimilados comunitarios y extranjeros, haciendo depender la titularidad activa de los derechos estatutarios únicamente de la condición de residente. La residencia se convierte en elemento determinante de vinculación a la Comunidad, lo que refleja esa tendencia a la equiparación entre los derechos de los extranjeros residentes y los propios de la ciudadanía. En este sentido el Estatuto andaluz va por delante de todos los demás y de la legislación de extranjería, a la que, sin embargo, se halla vinculada la Comunidad andaluza. Sin embargo, en la medida en la ésta pueda disponer de la regulación concreta de los derechos estatutarios puede hacer efectiva la extensión de su titularidad de los extranjeros, pues, aunque la legislación estatal no lo haga, no cabe, a mi entender, reputar ilegítima una extensión autonómica de la titularidad de un derecho, a pesar de que la legislación estatal, sin impedirla expresamente, no la contemple.

También el artículo 10.1 de la propuesta de Estatuto para Castilla y León contempla la extensión de la titularidad los derechos a los extranjeros con vecindad administrativa en la Comunidad pero esta extensión no la efectúa directamente el Estatuto, como en el caso andaluz, sino que tendrán que hacerlo las leyes autonómicas que desarrollen los derechos. La extensión la efectuará, pues, el legislador autonómico que podrá modularla y determinarla en relación con cada derecho. Es verdad que citado precepto emplea la expresión "los derechos... se extenderán", lo que parece implicar un mandato y no sólo la mera posibilidad, como se desprende de los antes citados artículos 15.3 del Estatuto catalán y 11.2 del aragonés. Además, estos dos últimos preceptos no contienen una referencia expresa a los extranjeros sino «a otras personas" que pueden ser sólo los ciudadanos de la Unión Europea o también los extranjeros o los mismos españoles no residentes.

Consideración particular merece la extensión de los derechos de participación, por un lado, a los ciudadanos españoles que tuvieron su última residencia en España en la concreta Comunidad autónoma, y a sus descendientes inscritos como españoles; y, por otro lado, a los extranjeros ya sean comunitarios o no. Ambos supuestos están previstos en la LOREG o en leyes electorales autonómicas. Esta pluralidad legislativa debe tenerse en cuenta al fijar el alcance de las cláusulas estatutarias. El artículo 3.2 del recientemente reformado Estatuto de Valencia y el artículo 9.2 del nuevo Estatuto de las Islas Baleares, lo mismo que el artículo 4.2 del Estatuto de Aragón, el artículo 5.1 de la propuesta canaria y el artículo 3.2 de la propuesta para Castilla La Mancha prevén ese ejercicio de los derechos de participación respecto de las instituciones autonómicas, y en todos estos preceptos hay una remisión a la ley estatal. 
En parecidos términos se expresa el artículo 7.2 del Estatuto catalán, aunque en éste la remisión a la ley no se acompañe de la aclaración de que la ley es la estatal. No obstante la omisión, será, en efecto, la ley estatal la que determine la forma en la que los españoles residentes en el extranjero y sus descendientes podrán solicitar su reconocimiento a los efectos de ejercer sus derechos de participación, tanto respecto de las instituciones estatales como de las autonómicas.

También en relación con los derechos de participación de los españoles, el Estatuto andaluz es el más aperturista ya que su artículo 5.3 dispone: “...dentro del marco constitucional se establecerán los mecanismos adecuados para promover la participación de los extranjeros residentes en Andalucía". Lo que completa el art. 30.2 (en una versión suavizada de la más aperturista contenida en la propuesta) estableciendo que: "La Junta de Andalucía establecerá los mecanismos adecuados para hacer extensivo a los ciudadanos de la Unión Europea y a los extranjeros residentes en Andalucía los derechos contemplados en el apartado anterior (es decir, los de participación política), en el marco constitucional y sin perjuicio de los derechos de participación que les garantiza el ordenamiento de la Unión Europea."

El estatuto andaluz impone en estas dos cláusulas citadas, bien que de una forma laxa, al legislador autonómico el establecimiento de mecanismos de participación de extranjeros residentes con independencia de que sean comunitarios o no. Ello supondría, por ejemplo, reconocimiento en su favor del derecho de sufragio en elecciones autonómicas. Se materializaría el principio de que los destinatarios de las normas deben participar en su elaboración, más allá de que el propio, estatuto se refiera a pueblo andaluz.

La regulación del Estatuto catalán contrasta vivamente en este punto con el Estatuto andaluz, a pesar de la semejanza que, como hemos visto, presentan sus respectivas declaraciones de derechos. El Estatuto catalán parte de la existencia de la Nación catalana, el sujeto protagonista del Estatuto. Este expresaría la voluntad de aquélla así que, en un planteamiento parejo al que se hace a escala estatal (el soberano es el pueblo español y sólo quienes lo forman, los ciudadanos españoles, pueden participar políticamente), el artículo 29 del Estatuto catalán reserva expresamente los derechos de participación, salvo el de petición, a los ciudadanos de Cataluña. En efecto, cinco de los seis apartados del citado artículo 29, salvo el mencionado relativo al derecho de petición, comienzan con la especificación de "los ciudadanos de Cataluña". De ello se infiere que la cláusula de extensión de la titularidad de los derechos estatutarios (artículo 15.3 del Estatuto catalán) no podrá servir para reconocer los derechos de participación a los no catalanes, pues el Estatuto los reserva expresamente a los ciudadanos de Cataluña.

Los demás estatutos de autonomía, nuevos o en proceso de reforma, también reservan los derechos de participación estatutaria a los ciudadanos respectivos (artículo 9 del Estatuto de Valencia, artículo 8.2 del balear, artículo 15 del aragonés (aunque el artículo 4.3 abra la puerta a una extensión de la participación a los extranjeros residentes), artículo 11 de la propuesta de re- 
forma para Castilla y León y art. 11 de la propuesta para Castilla La Mancha).

Este panorama general de reserva férrea de los derechos de participación para los ciudadanos de la comunidad respectiva, con la sola excepción de los españoles residentes que tuvieran su última residencia en la comunidad autónoma, y sus descendientes, contrasta vivamente con la regulación andaluza que introduce así una radical novedad.

\section{B) Sujetos pasivos}

$\mathrm{Al}$ referirnos a la naturaleza, fundamental o no de los derechos estatutarios apuntábamos más atrás que los estatutos declaraban su vinculación para los poderes públicos de la Comunidad respectiva. ${ }^{117}$ Advertíamos, empero, que con la remisión al posterior desarrollo legislativo venía a reconocerse, dada la naturaleza generalmente prestacional de los derechos estatutarios, que estos sólo podría efectivamente ejercerse en los términos previstos por el legislador autonómico, de tal suerte que la determinación de cuáles prestaciones habría de satisfacer la administración autonómica dependían de lo dispuesto en la ley. Así las cosas, el directamente vinculado por el estatuto era el legislador autonómico. El grado de vinculación de éste era considerable al recaer sobre él, tanto la regulación directa de los derechos como la prevista de los principios rectores que los nuevos estatutos venían a incluir.

La vinculación del legislador autonómico se desprende, como explicábamos más atrás, tanto si expresamente el respectivo estatuto dispone que los derechos vinculan a todos los poderes públicos autonómicos, entre los que se incluye, claro está, al parlamento, como si no hay tal vinculación expresa, pues va de suyo que el legislador autonómico está constreñido por la norma institucional básica de su Comunidad.

Más problemático, sin embargo, es determinar si, en ausencia de vinculación expresa, puede colegirse, además de la vinculación del legislador, la de los demás poderes públicos autonómicos, en otras palabras si potencialmente los titulares de los derechos podrían hacerlos valer, aún en ausencia de desarrollo legal, ante la administración y los tribunales. Como la mayoría de los derechos estatutarios requieren un desarrollo legal que permita su efectivo ejercicio, el problema se resuelve por sí solo, ya que, con independencia de que en el estatuto se disponga la vinculación de todos los poderes públicos a los derechos, el ejercicio de éstos depende de la ley correspondiente.

Habrá que concluir también en que los municipios y las diputaciones provinciales son sujetos pasivos de los derechos estatutarios pues a pesar de su propia autonomía, quedarán sometidos a los derechos invocales en su ámbito de actividad, como lo están a la regulación estatutaria de la autonomía local.

117 En la línea de lo que ocurre en los Estados federales en los que las cartas estatales no vinculan a la federación, CASTELLÁ, ob. cit., p. 22. 
Una problemática distinta se plantea con la ya apuntada declaración normativa de la eficacia frente a particulares de los derechos estatutarios cuya naturaleza así lo permita. Apuntábamos que la naturaleza prestacional de la mayor parte de los derechos estatutarios hace imposible su eficacia interprivatos. Hay, empero, excepciones, algunas contempladas en los estatutos como ocurre con el ejercicio del derecho de opción lingüística (artículo 33 del Estatuto catalán) que supone obligaciones expresas para los particulares, empresas y establecimientos abiertos al público, sujetos al "deber de disponibilidad lingüística" (artículo 34 del Estatuto catalán). Ni el Estatuto valenciano ni el balear establecen un régimen semejante. Tampoco estos dos últimos imponen al Estado las obligaciones que el Estatuto catalán deriva del derecho de opción lingüistica, el único que vincula también a la administración del Estado en Cataluña, e incluso fuera de ella en un curioso ejemplo de extraterritorialidad. Esta vinculación de los poderes públicos estatales en Cataluña se recoge en el artículo 37.1 del Estatuto y se desarrolla en su artículo 33 y viene doctrinalmente justificada por el carácter de ley estatal del estatuto. Porque el estatuto es ley estatal, el Estado puede vincularse a los derechos en él declarados. Así la propuesta aprobada por el Parlamento catalán (art. 37.1) extendía la vinculación de los derechos estatutarios a "todos los poderes públicos que actúan en Cataluñan. Tras su paso por las Cortes Generales esta universal vinculación se redujo al derecho de opción lingüística y al consiguiente deber de disponibilidad lingüística.

Respecto del derecho de opción lingüística, tanto la administración electoral estatal en Cataluña como la administración de justicia, el ministerio fiscal, el notariado y los registros públicos han de atender en catalán (artículo 33.2 del Estatuto), para satisfacer el derecho de opción lingüística que permite a los ciudadanos catalanes elegir la lengua con la que desean relacionarse con cualquier administración, incluida la estatal en Cataluña. De lo anterior se colige la obligación de jueces, fiscales, notarios, registradores y demás personal al servicio de la administración de justicia de demostrar conocimiento adecuado y suficiente" de las dos lenguas oficiales, incluido por supuesto el catalán (artículo 33.3). En general, se exige a toda administración del Estado presente en Cataluña disponer de personal que atienda en catalán (artículo 33.4). Para cerrar la regulación el artículo 33.5 introduce la extraterritorialidad ya apuntada, pues reconoce el derecho de "relacionarse por escrito en catalán" con los órganos constitucionales y con los órganos jurisdiccionales de ámbito estatal. Ni el Estatuto valenciano ni la propuesta balear extienden la vinculación del derecho de opción lingüística a los poderes públicos estatales presentes en los respectivos territorios.

Aunque los estatutos que declaran la vinculación de los derechos a los poderes públicos se refieren expresamente a los poderes públicos autonómicos, con la excepción lingüística catalana que extiende la vinculación de los derechos lingüísticos a la administración estatal, es obvio que los tribunales de justicia se hayan también concernidos, pues han de interpretar y aplicar el derecho autonómico empezando por el respectivo estatuto. En consecuencia, 
también las normas estatutarias que proclaman derechos vinculan a los tribunales, si bien lo hacen de forma modulada, según la naturaleza del derecho, pues los derechos prestacionales dependen, para su posible invocación ante los tribunales, de la necesaria mediación del legislador. Prueba de lo anterior es que los estatutos que más resaltan la fuerza vinculante de los derechos no olvidan reclamar su desarrollo al legislador autonómico, bien en una carta que los reúna, bien con su regulación individual. Es, por tanto, la naturaleza de cada derecho estatutario la que permitirá o no su posible aplicabilidad directa ante los tribunales, pero la verdadera incidencia de los estatutos se produce en el dominio de los derechos prestacionales cuya satisfacción corresponde a las CCAA porque son competentes en esas materias. Cuando las Comunidades ejerzan esas competencias concretas y desarrollen los derechos, entonces los ciudadanos podrán invocarlos y los tribunales hacerlos valer.

\section{ARTICULACIÓN DE LOS DERECHOS ESTATUTARIOS CON LOS DERECHOS CONSTITUCIONALES}

La necesidad de articular derechos estatutarios y derechos constitucionales es rigurosa novedad en la historia constitucional española, y quizás por eso asuste un poco el reto de atenderla como es debido. Se trata, sin embargo, de lo cotidiano en los Estados compuestos donde, por regla general, coexisten declaraciones estatales con la declaración federal. ${ }^{118}$ La declaración federal operaría como un estándar de mínimos, ${ }^{119}$ lo mismo que sucederá en España, ${ }^{120}$ de tal suerte que, como disponen los artículos 37.4 del Estatuto catalán, 13.1 del Estatuto andaluz y 6.3 del aragonés, los derechos estatutarios no podrán ser desarrollados ni aplicados de modo que limiten o reduzcan los derechos proclamados en la Constitución o en los tratados internacionales ratificados por España.

Como hemos comprobado, la duplicidad de declaraciones en España no supone, al contrario de lo habitual en los Estados federales, una duplicidad de contenidos. Allí donde hay duplicidad es porque se trata de materias compartidas donde pueden legislar tanto el Estado como las CCAA (educación, sanidad, participación política, etc.). Las declaraciones estatutarias, en general, omiten referirse a los derechos clásicos de libertad para centrarse en los derechos prestacionales cuya satisfacción corresponde a las CCAA, por gestionar

118 Relación entre declaraciones que CASTELLÁ explica en términos simbólicos y de competencia para declarar mejor los derechos, ob. cit., pp. 27 y 28.

119 Como explican TARR, en relación con el caso estadounidense, ob. cit., pp. 44 y ss., HARTWIG, respecto del caso alemán, ob. cit., pp. 156 y ss. y ROSSI, respecto del caso italiano donde el nuevo art. 117 constitucional establece que el Estado fijará "...los niveles esenciales de las prestaciones relativas a los derechos civiles y sociales que deben ser garantizados en todo el territorio nacional", ob. cit., pp. 209 y ss.

120 Situación que apuntan, entre otros, CARRILlO, ob., cit., p. 89. También MUÑOZ MACHADO, «El mito....", ob. cit., p. 76. 
ellas los servicios públicos pertinentes. A priori, la armonización de las declaraciones de derechos autonómicas con la estatal resulta más sencilla pues las autonómicas pretenden completar e integrar la estatal y no competir con ella y sustituirla.

En los Estados federales, como las autoridades estatales se hallan sometidas a los derechos reconocidos en la Constitución federal ${ }^{121}$ y no sólo a los derechos propiamente estatales, los ciudadanos pueden optar entre acudir a los tribunales federales o a los tribunales estatales ${ }^{122}$. En España no hay opción de acudir a circuitos judiciales distintos porque la defensa de los derechos constitucionales, como la de los estatutarios, corresponde a los tribunales integrados en el poder judicial. Lo que se producirá probablemente es que se abra una duplicidad de procedimientos judiciales, pero residenciadas ambas vías procesales en el único poder judicial existente.

Por ello es conveniente que se vayan decantando competencialmente los espacios materiales donde se apliquen cada una de las tablas de derechos, aunque esta tarea viene dificultada por la asimetría que llevan presentando los nuevos estatutos de autonomía. Alguno como el canario renuncia a recoger una declaración y opta por fijar objetivos de la política autonómica (artículo 7 de la propuesta Canaria), de índole social sobre todo. El Estatuto de Valencia mezcla objetivos con el reconocimiento de algún derecho concreto y se remite a una carta de derechos sociales (artículo 10.2). La mayor parte de los estatutos nuevos contienen derechos sociales pero no siempre regulados con la misma amplitud y perviven estatutos sin declaración de derechos. Va de suyo que allí donde no alcance el derecho estatutario concreto, porque no lo haya o porque carezca de amplitud, puede llegar el derecho constitucional si lo hubiere.

El panorama revela toda su complejidad, aún más si tenemos en cuenta que también entran en juego las legislaciones estatales y autonómicas que desarrollan los respectivos derechos, muchos de ellos, en especial los estatutarios, de carácter prestacional. Despejar este panorama corresponde a los tribunales ordinarios que asumen la pesada carga de armonizar el disfrute de los viejos derechos constitucionales con los nuevos derechos estatutarios. En esta tarea no va a ser de gran ayuda el TC, como veremos en el epígrafe ocho de este estudio. Donde acaso intervenga TC será a la hora de determinar la constitucionalidad de las posibles limitaciones a derechos constitucionales que introduzcan los estatutos o la legislación autonómica. ${ }^{123}$

Desglosemos ahora los diferentes tipos de supuestos con los que se pueden enfrentar los tribunales. En todos ellos estaremos ante actuaciones pro-

121 Un buen análisis de derecho comparado acerca de este extremo lo ofrece CASTELLÁ, ob. cit., pp. 21 y ss. Sobre la evolución en los Estados Unidos, cfr, TARR, ob. cit., pp. 56 y ss.

122 Lo que plantea notables problemas, como destaca DÍEZ-PICAZO en relación a la experiencia estadounidense, ob. cit., pp. 67 y ss.

123 Cfr. en este sentido BRAGE, ob. cit., pp. 206 y ss., CASTELLÁ, ob. cit., p. 29. Alessandro PACE alerta contra la proclamación de nuevos derechos que implican limitaciones de los derechos constitucionales, Problemática delle libertá costituzionali, CEDAM, Padua, 2003. 
tagonizadas por los poderes públicos autonómicos, dejando a salvo la legislación autonómica de cuyo control hablaremos en el siguiente epígrafe y que sólo puede evacuar el TC. En el caso catalán, además, puede darse el supuesto de que la actuación controlada por los tribunales sea la de la administración estatal presente en Cataluña, incluso fuera de ella, en relación con el ejercicio del derecho de opción lingüística. Los tribunales revisarán la actividad de los poderes públicos autonómicos tanto cuando aplican el derecho propio como cuando aplican el derecho estatal. En ambos casos habrán de respetar los derechos estatutarios, pero asimismo los derechos constitucionales y sus respectivas legislaciones de desarrollo. Los tribunales verificarán que este doble sometimiento ha sido efectivo. Pero este doble sometimiento es el punto de partida en abstracto, la doble vinculación de los poderes públicos autonómicos, lo que no significa necesariamente que deban, en cada caso concreto, proyectarse tanto el derecho constitucional como el derecho estatutario; por lo general uno u otro se proyectarán con preferencia y la determinación de esta preferencia corresponderá a los tribunales.

\section{NO DUPLICACIÓN ESTATUTARIA DE DERECHOS CONSTITUCIONALES}

El primer supuesto posible es el de no duplicación cuando es único el derecho que el poder público autonómico debe respetar. Este supuesto tiene dos caras, la primera si el único derecho es el constitucional, y la otra si es un derecho estatutario. Se trata, claro está, del supuesto más fácil de resolver. Por ejemplo si el derecho afectado es el de propiedad, serán la Constitución y la legislación estatal de desarrollo las normas aplicables. O bien si es un derecho estatutario nuevo que carece de parangón en la Constitución, aplicables serán la norma estatutaria y la legislación autonómica que la desarrolle.

No siempre, empero, la situación es tan sencilla y, en ocasiones, podría suceder que el derecho estatutario sea nuevo sólo en apariencia y que en realidad se trate de una posición jurídica individual que pudiera adscribirse a un derecho constitucional. Podríamos extraer varios casos en los estatutos, sirva de ejemplo el, por otro lado loable, derecho a una especial protección contra la violencia de género que reconoce a las mujeres el artículo 16 del nuevo Estatuto de Andalucía. A mi modo de ver, este derecho viene comprendido en el derecho a la integridad personal ${ }^{124}$ proclamado en el artículo 15 de la Constitución, de lo que resultaría que la legislación estatal en defensa de la integridad femenina, que ya existe, concurrirá con este derecho del nuevo Estatuto andaluz y con la legislación que en el futuro lo desarrolle.

Podría también acontecer que, si bien no haya duplicación, las legislaciones respectivas introduzcan limitaciones. Se ha estudiado ${ }^{125}$ como las CCAA

124 Raúl CANOSA USERA, El derecho a la integridad personal, Lex Nova, Valladolid, 2006, pp. 206 y ss.

125 Fenómeno bien explicado por BRAGE, ob. cit., pp. 189 y ss. 
pueden introducir limitaciones en el ejercicio de los derechos constitucionales. Ahora, con los nuevos estatutos sucederá que la legislación estatal limitará de una suerte u otra suerte el ejercicio de derechos estatutarios. Estos últimos, a su vez, justificarán potenciales restricciones del ejercicio de derechos constitucionales (lo que ocurre por ejemplo con el derecho de opción lingüística catalán).

\section{Duplicación estatutaria de Derechos constitucionales en Ámbitos EN QUE LAS COMUNIDADES AUTÓNOMAS SON COMPETENTES}

Como ya he apuntado los derechos estatutarios se ejercen en ámbitos materiales sobre los cuales las CCAA poseen competencias específicas, lo que virtualmente convierte la regulación de tales derechos en una competencia autonómica dentro de sus ámbitos materiales en los que, sin embargo, puede el Estado incidir ex artículo 149.1.1 CE o invocando una competencia específica. Por emplear la distinción de Hesse ${ }^{126}$ el ámbito normativo en el que inciden las normas estatutarias reconocedoras de derechos en estos supuestos pertenece a las Comunidades, pero sólo parcialmente, porque son ámbitos compartidos o más bien concurrentes, pues también el Estado posee títulos competenciales para proyectarse en dichos ámbitos. Habrá un programa normativo autonómico pero sin exclusión del correspondiente estatal.

En estos casos la declaración estatutaria viene a integrar, completar, el derecho constitucional y, en ocasiones, por ejemplo en lo sanitario, a la legislación estatal. Esta integración conlleva la concurrencia de regulaciones distintas, la estatal y la autonómica, que genera un conflicto cuya resolución permitirá saber cuál norma se aplica o, si es posible, cómo se conjuga la aplicación de ambas regulaciones. En estos supuestos son invocables los derechos reconocidos a escala estatal, sobre todo por la Constitución pero también su desarrollo legal, así como los derechos estatutarios y la legislación correspondiente. Los ámbitos materiales donde se producirá esta concurrencia son los mismos en los que el Estado y las Comunidades comparten materias. Sucede, sin embargo, que, en el caso de las materias compartidas, el criterio es, por lo general, que la norma estatal regula lo básico y la norma autonómica lo desarrolla, disponiéndose así de dos partes de la misma materia cuya separación traza la ley básica estatal (legislación susceptible de control por parte del TC desde su concepción material de lo básico), más allá de la cual el resto de la materia queda al albur de las CCAA.

En materia de derechos esta compartimentación de la materia no puede hacerse, más bien hay una verdadera concurrencia de dos regulaciones, la estatal y la autonómica, que versan sobre la misma materia: un derecho cualquiera. Así, por ejemplo, en materia de participación política, sanidad, educa-

126 Distinción ente programa normativo y ámbito normativo, Escritos de Derecho Constitucional, CEC, Madrid, 1983, pp. 46 y ss. 
ción, las declaraciones estatutarias son más completas reproduciendo, en ocasiones, los contenidos de la proclamación constitucional o de la legislación estatal y, a menudo, completándolas con contenidos nuevos o más detallados. Si aplicamos sin más el criterio de prevalencia del derecho estatal competente, las declaraciones estatutarias y su desarrollo legislativo quedarían postergados. Es una senda inviable, así que mejor sería optar por alguno de estos dos criterios: el de mayor especificidad o el de mayor protección, especialmente el segundo, o una combinación de los dos. Conforme al primero daríamos preferencia a la norma autonómica, pero no cuando ofrezca una protección menor de la brindada por la legislación estatal, únicamente si, dando una protección más concreta, ésta no fuera menor que la brindada por el derecho estatal. ${ }^{127}$

Si en caso de concurrencia la protección autonómica del derecho es mayor, entonces serán las normas autonómicas las aplicables. Desde el punto de vista competencial, en materia de derechos, se operaría como se opera en materia ambiental: la legislación básica fija unos estándares mínimos de protección que pueden superar las Comunidades. Pues bien, en materia de derechos sucedería algo parecido: el mínimo común denominador lo marcaría el estado ex artículo 149.1.1 CE o en virtud de otras competencias propias (en algunos casos la legislación estatal podría ir más lejos), pero las Comunidades, en ejercicio siempre de competencias concretas, podrían mejorar la protección estatal. Naturalmente la legislación autonómica incompetente sería inconstitucional, aunque mejorara el estándar fijado por el Estado. Este modo de argumentar respondería, además, al criterio favor libertatis, preferencia de la interpretación más favorable a la efectividad de los derechos, pero no de los derechos estatutarios sino de los derechos constitucionales; esto se realizaría mejor si la regulación aplicada fuera la autonómica siempre que ésta brindara mayor protección a los derechos constitucionales y la Comunidad tuviera competencia para incidir en su ámbito normativo.

\section{Duplicación estatutaria de Derechos Constitucionales SIN COMPETENCIA DE DESARROLLO}

La omisión estatutaria de la gran mayoría de los derechos reservados a la ley orgánica y otros en cuyo ámbito normativo sólo es competente el Estado (por ejemplo el derecho de propiedad o la libertad de empresa) favorece el encaje de las declaraciones estatutarias con el sistema constitucional de protección de la libertad. No desaparecen los problemas de articulación que venimos comentando pero se encauzan a través de la lógica de nuestro Estado compuesto, dirimiéndose los conflictos según el criterio de competencia, lo que implica descartar una legislación autonómica sobre derechos acerca de

127 Por eso, para MUÑOZ MACHADO, es legítimo reproducir derechos constitucionales pero no negarlos o rebajar su contenido, "El mito...", ob. cit., p. 76. 
los cuales las CCAA carezcan de competencia. Esta lógica no impide, desde luego, que las Comunidades, al ejercer sus competencias, incidan e incluso restrinjan derechos constitucionales a los cuales no haya referencia en sus estatutos, pero esta incidencia no implica el desarrollo de los derechos estatutarios que, en virtud de sus específicas competencias, pueden acometer si se hubieran recogido en los estatutos derechos que sólo puede desarrollar el Estado mediante ley orgánica ex artículo 149.1.1 CE o en virtud de otros títulos competenciales, habría generado un conflicto que no podrían resolver los tribunales y que antes tendría que atajar el TC. Habría sido, además, inútil y las disposiciones estatutarias que en tal error incurrieran quedarían depreciadas en su valor normativo y sería incompetente toda legislación autonómica que las desarrollase, si es que antes el TC no declarase la inconstitucionalidad de dichos preceptos estatutarios.

Hasta ahora nos hemos planteado en este epígrafe la resolución judicial de los conflictos que la regulación estatutaria y legislativa autonómica de los derechos suscitaba en los casos de actuación de la administración autonómica. En el epígrafe siguiente nos ocuparemos de lo que sucede cuando la actuación enjuiciable es la del propio legislador autonómico. En estos supuestos, sentada la constitucionalidad del correspondiente estatuto, el único competente es el Tribunal Constitucional.

\section{GARANTÍAS DE LOS DERECHOS ESTATUTARIOS}

El reconocimiento de derechos en los estatutos genera una nueva tarea para las Comunidades que ahora han de ocuparse de la protección de los derechos estatutarios, a través de los mecanismos de protección que en algunos casos prevén los propios estatutos o mediante otros que ya existan en el ordenamiento estatal o que sean introducidos por el Estado para encauzar, sobre todo, la tutela jurisdiccional. Del Estado se reclama, por tanto, lo que no está en las manos de las Comunidades acometer, es decir, modificar la legislación procesal para crear cauces específicos de tutela de los nuevos derechos. En el terreno de las garantías ${ }^{128}$ está en juego el verdadero carácter de derechos de los reconocidos en los estatutos, pues si no gozarán de protección jurisdiccional se desvirtuaría su pretendida naturaleza y fungirían sólo como principios. Y es en este terreno donde más dificultades hallamos porque las CCAA carecen de un poder judicial propio del que puedan disponer, ${ }^{129}$ aunque algunos estatutos intenten condicionar al legislador procesal estatal para que abra vías de tutela específicas de los derechos estatutarios.

No todos los nuevos estatutos prevén expresamente garantías específicas de los derechos en ellos reconocidos. Únicamente los ya aprobados Estatutos

128 Un análisis sistemático lo ofrece CARRILLO, ob. cit., pp. 81 y ss.

129 Incongruencia que denuncia MARTÍN RETORTILLO, ob. cit., p. 16. 
catalán (artículos 38 y 39), y andaluz (artículo 39), la propuesta para Castilla y León (artículo 17) y la propuesta para Castilla La Mancha (artículo 22). El esquema de estos preceptos es similar (aunque la de la propuesta castellano manchega sea más sencilla); recogen, en un primer lugar, la vinculación de todos poderes públicos autonómicos a los derechos estatutarios, así como la eficacia entre particulares de los derechos que por su naturaleza lo permita, precisiones éstas a las que hemos hecho dilatada referencia en epígrafes anteriores; en segundo lugar, se contempla la reserva de ley ya que sólo parlamento respectivo puede desarrollar los derechos, bien individualmente bien a través de una carta; en tercer lugar, se anticipa la protección de los tribunales según los procedimientos que se determinen; y en último lugar, se introduce la cláusula favor libertatis que, en puridad, no es una garantía sino un criterio jurisprudencial que, al imponerse normativamente, acaba operando como tal. Ninguno de los estatutos citados modula la eficacia de los derechos, distinguiendo entre ellos, así que todos los declarados son iguales a la luz del correspondiente estatuto.

De los estatutos citados, el catalán es el que más afina el esquema de garantías, primero, porque extiende la vinculación del derecho de opción lingüistica a la administración estatal presente en Cataluña, y, segundo, porque prevé una suerte de "recurso de amparo" catalán ante el Tribunal Superior de Justicia de Cataluña (artículo 38.2 del Estatuto), si bien este recurso debe desarrollarlo el legislador estatal modificando sus leyes procesales. Por añadidura el artículo 38.1 asigna al Consejo de Garantías Estatutarias, nombre nuevo del anteriormente existente Consejo Consultivo, la función (artículo 76) de dictaminar, entre otros, los proyectos y proposiciones de ley que desarrollen o afecten derechos estatutarios. ${ }^{130}$ En este caso —el único- el dictamen es vinculante, de tal modo que, en relación con este tipo de iniciativas legislativas, las relativas a derechos, su decisión es vinculante, operando como una suerte de control previo sobre el proyecto o proposición de ley ${ }^{131}$ para comprobar que se respetan los derechos estatutarios. Si el dictamen es negativo, al ser vinculante, no podrá continuarse el procedimiento legislativo.

Hay que precisar, además, que los dictámenes del Consejo de Garantías no se elaboran únicamente sobre iniciativas del gobierno autonómico, sino sobre cualquier otra iniciativa legislativa con independencia de su procedencia. Así las cosas, este Consejo opera como un filtro de toda innovación legislativa para comprobar su adecuación a la Constitución y al Estatuto, lo que le convierte en un órgano que participará en la interpretación constitucional, ${ }^{132}$ situación verdaderamente única en nuestra experiencia constitucio-

130 También el art. 22.2 de la propuesta de reforma para Castilla La Mancha prevé el informe previo de los Consejos Consultivo y Económico Social de la CA, pero no dispone el efecto vinculante de sus dictámenes.

131 Este control preventivo y vinculante aproxima al Consejo Consultivo al Consejo Constitucional francés como advierten CARRILLO, ob. cit., p. 84 y VIVER, ob. cit., p. 33.

132 CARRILLO, ob. cit., p. 85. 
nal. El riesgo es el de desplazar al Tribunal constitucional con menoscabo de su competencia. ${ }^{133}$ En todo caso, el control preventivo de la compatibilidad entre proyectos y proposiciones de leyes autonómicas y los derechos estatutarios acaso sea el único modo eficaz de asegurarla.

Un mecanismo de tutela jurisdiccional de los derechos estatutarios se prevé en los artículos 38.2 del Estatuto catalán, 39 del andaluz, y 22.4 del la propuesta de reforma de Castilla La Mancha. El precepto catalán es el que mejor define el recurso, un recurso ante el Tribunal Superior de Justicia de Cataluña. Se trata de una suerte de "recurso de amparo catalán" ${ }^{134}$ que deberá perfilar la Ley Orgánica del Poder Judicial, es decir, una ley estatal. Si, como parece exigir el citado artículo 38.2, se acaba estableciendo un recurso directo de única instancia, es previsible el colapso del sistema ante el aluvión de acciones. Acaso conviniere introducir una instancia previa. ${ }^{135}$

El artículo 38.2 del Estatuto catalán condiciona al futuro legislador procesal estatal al prefigurar el recurso de "amparo" catalán, ${ }^{136}$ mientras que los otros tres estatutos (art. 39 del andaluz, 17.1 de la propuesta castellano leonesa y 22.4 de la castellano manchega) sólo preanuncian la necesaria tutela jurisdiccional de los derechos estatutarios, sin condicionar la libertad de configuración del legislador estatal. Ahora bien, la acción de éste es indispensable para que la tutela jurisdiccional futura de estos derechos sea eficaz.

La reserva del desarrollo de los derechos a la ley autonómica concreta la vinculación positiva del legislador sin que éste pueda eludir la tarea asignada. La reserva y las demás garantías aproximan el esquema autonómico de garantías al previsto en el artículo $53 \mathrm{CE}$ para los derechos constitucionales. En efecto, el deliberado propósito de impedir que los derechos estatutarios queden devaluados, como ha sucedido en Italia, convertidos en meras orientaciones políticas para los poderes públicos regionales. ${ }^{137} \mathrm{Tal}$ cosa no puede suceder en España, salvo que se declarasen ilegítimos los preceptos estatutarios que prescriben los instrumentos de garantía, pues estos reproducen el sistema estatal del artículo 53, y incluso, para fundar mejor y marcar las diferencias, disponen que los principios rectores, que los estatutos contienen, cumplirán en el ordenamiento jurídico autonómico la misma función que el artículo 53.3 $\mathrm{CE}$ asigna a los principios rectores de la política social y económica recogidos

133 Peligro frente al que alerta GARCÍA TORRES, ob. cit., pp. 71 y ss. y que niega CARRILLO, ob. cit., p. 85.

134 Como lo denomina GARCÍA TORRES, ob. cit., p. 66. y explica CARRILLO, ob. cit., p. 87. GARCÍA ROCA considera que hay invasión en la reserva a favor de las leyes procesales y de la LOPJ, "El riesgo...", ob. cit., pp. 101 y 102.

135 VIVER se refiere a una hipotética instancia autonómica, no jurisdiccional, que con suspensión de los plazos para acudir a la jurisdicción, pudiera resolver las posibles lesiones de los derechos estatutarios, ob. cit., p. 33.

136 CARRILLO la califica de "leve predeterminación," ob. cit., p. 87.

137 ROSSI se refiere a la "sustancial imposibilidad" de establecer formas de garantía en los estatutos regionales italianos, aprobado, sin intervención estatal por los entes regionales, pero sin poder judicial propio, ob. cit., p. 229 
en el Capítulo III del Título I de la Constitución. En efecto, los artículos 39 del Estatuto de Cataluña, 40 del andaluz y 17.3 de la propuesta castellano leonesa prevén para los principios rectores estatutarios la misma eficacia normativa programática que prevé el artículo 53.3 CE citado. Se marcan así las diferencias entre la inmediata vinculación de los derechos y la "diferida" de los principios rectores, haciendo en principio imposible para el intérprete futuro de los estatutos un entendimiento de los derechos que los rebajase a meros principios programáticos, equiparándolos con los que verdaderamente lo son.

El único aspecto del artículo $53 \mathrm{CE}$ no reproducido en los preceptos de los estatutos que estamos analizando es no recogen una referencia expresa al contenido esencial de los derechos; sólo se refiere al "contenido" el artículo 38 del Estatuto andaluz. Ello no supone que los derechos estatutarios carezcan de un contenido indisponible para el legislador que debe desarrollarlos, pues esta indisponibilidad tiene por necesidad que inferirse de la propia fuerza vinculante de los derechos respecto del legislador. ${ }^{138}$ De lo contrario, el legislador gozaría de total discrecionalidad y su vinculación a los derechos no tendría sustancia alguna. La interpretación de estos preceptos estatutarios debe ser la de afirmar que existe una vinculación del legislador al contenido estatutariamente declarado de cada derecho. Ya se ha apuntado que la referencia al contenido esencial es en cierto modo superflua, pues va de suyo que la vinculación del legislador a los derechos no es un rótulo vacío sino materialmente definido por el contenido declarado en la norma de derecho fundamental o consustancial al propio derecho. Su vinculación a los derechos impide al legislador vaciarlos de contenido dejándolos irreconocibles.

Cabe preguntarse ahora si aquellos estatutos de autonomía que nada prevén acerca de las garantías renuncian a la protección inmediata de sus derechos y los rebajan a meras normas programáticas. Esto pudiera pensarse de la recién aprobada reforma del Estatuto de Valencia que no introduce una sistemática declaración de derechos sino que se limita a reconocer derechos sueltos y principios rectores, remitiéndose a una ley de su parlamento para que elabore una carta de derechos sociales (artículo 10.2). Aún así este Estatuto recoge unos derechos a los que no cabe, sin más, privar de su condición de tales y, menos aún, en el caso del Estatutos balear y de las propuestas de reforma aragonesa y castellano manchega, que sí contienen una declaración sistemática. ¿̇uede inferirse, aunque no se contengan expresamente, garantías similares a las recogidas en los estatutos catalán, andaluz, castellano leonés y castellano manchego o hay que concluir en que la falta de tales garantías devalúa la posición de los derechos reconocidos? ¿Se trata de una omisión consciente o de un simple olvido? Lo natural y más conveniente sería que los derechos en todas las Comunidades gozasen de un régimen de garantía similar y se les reconociese la naturaleza de verdaderos derechos pues así han sido formulados en los estatutos, vengan o no acompañados de específi-

138 Como deja claro CARRILLO, ob. cit., p. 73. 
cas garantías. Pero la asimetría existe, todavía hay estatutos sin derechos - los antiguos todavía vigentes - y algunos nuevos como el canario ha renunciado a incorporarlos ¿Debería el Estado imponer la simetría cuando su futura legislación procesal establezca las vías para la tutela de los derechos estatutarios? El tiempo irá decantando la verdadera fuerza normativa de estos derechos.

Como se reclama en los estatutos catalán y andaluz y en las propuestas castellano leonesa y castellano manchega, debería el Estado introducir en sus leyes procesales un procedimiento específico de tutela de los derechos estatutarios. Sin tal inclusión, el recurso de "amparo catalán" no podría operar y entonces habría que indagar la manera de recabar la tutela de los derechos a través de las vías actualmente existentes que se abrirían, sobre todo, cuando haya leyes autonómicas de desarrollo. El posible panorama futuro ofrecería al ciudadano la alternativa ${ }^{139}$ de reivindicar sus derechos estatutarios por la vía específica prevista en las leyes estatales o bien invocar los derechos constitucionales a través de los procedimientos ordinarios o de los procedimientos preferentes y sumarios si se tratase de derechos que pueden culminar ante el TC. Obvio es decirlo, la duplicidad de vías sería efectiva cuando el derecho comprometido tuviera doble reconocimiento, estatal y estatutario, no cuando se tratase de derechos sólo proclamados en la Constitución o sólo reconocidos en el respectivo estatuto. Ya hemos visto que son varios los ámbitos donde tal duplicidad de reconocimientos existe: el de igualdad, el de la participación, el de las peticiones, el sindical, el de la educación o el mismo sanitario.

Los Estados constitucionales del presente no sólo ofrecen medios para la defensa individual de los derechos frente actos de los poderes públicos e incluso frente particulares, también prevé mecanismos para defender los derechos frente al legislador democrático, de tal suerte que el control de constitucionalidad se convierte en instrumento idóneo de garantía de la libertad. En los Estados federales la tutela de los derechos declarados en las constituciones estatales se encomienda a los tribunales estatales e incluso al tribunal constitucional federal. ${ }^{140}$ En nuestro Estado autonómico sólo existe un poder judicial, estatal, y los órganos que lo componen carecen de competencia para controlar normas con rango de ley ya que tal función se atribuye en régimen de monopolio al TC, cuyo canon de enjuiciamiento es la Constitución.

A la vista la anterior ¿Cómo podemos imaginar un control de las leyes autonómicas para verificar su conformidad con los derechos en ellos reconocidos? Porque es claro que las leyes autonómicas pueden potencialmente infringir las normas estatutarias que reconocen derechos. Pero ¿algún tribunal podrá ocuparse del que podríamos llamar, con perdón por la cacofónica expresión, "control de estatutoriedad" de las leyes autonómicas?

139 Alternativa que explican TARR respecto a los EEUU, ob. cit., p. 52 y HARTWIG, respecto a Alemania, ob. cit., pp. 163 y ss.

140 Acerca del papel del Tribunal constitucional federal en derecho comparado, cfr. CASTELLÁ, ob. cit., pp. 33 y ss. 
Era obvio que la defensa de los estatutos frente a las leyes de los parlamentos autonómicos no cabía confiársela a los Tribunales Superiores de Justicia respectivos que se habrían convertido así en una suerte de tribunales constitucionales autonómicos, quebrando el monopolio del control de las normas con valor de ley que ostenta el TC; a éstos tribunales sólo podía atribuírseles, a lo sumo, lo que se le ha asignado al TSJ de Cataluña, el recurso de amparo catalán. De controlar la correspondencia entre las leyes autonómicas y los estatutos se ocupará, de acuerdo con el sistema vigente, el Tribunal Constitucional. Puesto que los estatutos forman parte del bloque de la constitucionalidad, es decir, del canon de enjuiciamiento del Tribunal Constitucional, una ley autonómica puede ser impugnada por la vía del recurso de inconstitucionalidad por supuesta infracción del estatuto o cuestionada ante el TC por un órgano judicial o, eventualmente, tras el otorgamiento de un amparo, por una Sala del TC, sin olvidar la posibilidad del conflicto e competencias.

Pero esta inclusión de los estatutos en el bloque de la constitucionalidad ha servido, con alguna excepción, ${ }^{141}$ para dirimir conflictos de competencias y siempre, incluso en estas excepciones, la infracción de la norma estatutaria implicaba la vulneración de un precepto constitucional, así que también entonces el estatuto operaba como canon de enjuiciamiento en conexión con alguna disposición constitucional. Nada de esto ocurriría si el TC considerase vulnerado un artículo estatutario reconocedor de un derecho pues éste no tendría conexión con disposición constitucional alguna. Así las cosas, ¿podría ahora impugnarse ante el TC una ley autonómica por vulnerar los derechos estatutarios? ¿Viene ampliado el uso del estatuto como canon de enjuiciamiento, extendiéndose también a los derechos estatutarios? Si respondiéramos que no, ateniéndonos al artículo 28.1 LOTC —según este precepto los estatutos sólo son parámetro del TC en las disputas competenciales o cuando existe vulneración simultánea del estatuto y de la Constitución-, entonces las vulneraciones de los derechos estatutarios mediante ley autonómica quedarían impunes y sólo el control previo, en el caso catalán, a través de los dictámenes vinculantes del consejo de Garantías estatutarias, podrá impedirlo. Este Consejo de Garantías se convertirá en el intérprete supremo de la declaración estatutaria. Lo que sería una solución para Cataluña, pero no para las demás Comunidades de nuevos estatutos con declaraciones que nada prevén acerca de un posible control preventivo vinculante.

Si respondiéramos que los derechos estatutarios se incorporan también al bloque de la constitucionalidad, ${ }^{142}$ entonces las normas que los proclaman

141 La STC 36/1981 declaró la inconstitucionalidad de la Ley vasca 2/1981, de 12 de febrero, que ampliaba la inmunidad de los parlamentarios vascos reconocida en el Estatuto. El TC, en el fto. J. 4, consideró que tal ampliación era una reforma estatutaria sin acogerse al procedimiento previsto en el propio Estatuto y que ello suponía infringir el art. 147.3 CE. No se plantea en este caso una disputa competencial sino una infracción mediata del art. 147.3 al ignorar el cauce de reforma estatutario.

142 Como defiende FERRERES, ob. cit., pp. 14 y ss. y parece que también BALAGUER CALLEJÓN (Coord.), El nuevo Estatuto de Andalucía, ob. cit., p. 37. 
operarían como verdaderas normas constitucionales defendidas por el TC que se transformaría en el supremo intérprete de los derechos estatutarios. Ninguna de las dos respuestas es satisfactoria. Una porque deja impunes las violaciones de los derechos cometidas por el legislador autonómico, la otra porque amplia, sin justificación en razones competenciales (ya que las normas declaratorias de derechos no atribuyen competencia alguna), el canon de enjuiciamiento del TC.

Hasta ahora el TC ha verificado la constitucionalidad formal — respecto del reparto competencial- de las leyes cuando ha empleado los estatutos como canon de enjuiciamiento. Los estatutos no han servido como parámetro material de constitucionalidad. Esto cambiaría radicalmente si el TC se ocupase de las funciones propias de un "tribunal constitucional autonómico." Se plantearía entonces una curiosa situación en la que el TC sería el intérprete supremo de los derechos constitucionales pero también de los estatutarios y habría que ver cuáles son los criterios que emplearía.

Desde luego es discutible que el recurso de inconstitucionalidad ${ }^{143}$ o la cuestión de inconstitucionalidad puedan utilizarse para la defensa de los derechos estatutarios frente a leyes autonómicas. Para empezar sería un control cuyo objeto se restringiría a las leyes autonómicas y no a las estatales, lo que no ocurre cuando se efectúa el control competencial proyectado tanto sobre normas estatales como sobre las autonómicas. Esto último sucede porque los estatutos forman parte del bloque de la constitucionalidad únicamente cuando vinculan tanto al Estado como a la respectiva CA, al deslindar competencias entre ellos. Sin embargo, la parte dogmática de los estatutos sólo afecta a la CA respectiva, de tal modo que si el TC efectuara ese control de «estatutoriedad" no efectuaría control de constitucionalidad alguno sino que actuaría desdoblado en una suerte de tribunal constitucional de la CA concernida - lo que no está previsto ni en la Constitución ni en la LOTC_- y operaría desde el estatuto — canon distinto- y sobre un objeto limitado — las leyes autonómicas - Cabe imaginar esta opción pero, a mi entender, para ponerla en marcha se requeriría, al menos, una reforma de la LOTC, pues los procedimientos existentes no son aptos, en especial el recurso de inconstitucionalidad, para encauzar lo que sería una nueva tarea del TC.

Así, respecto a la legitimación en el recurso, el Defensor del Pueblo estatal no interpondría un recurso para la defensa de derechos estatutarios, cuya defensa no le corresponde; tampoco parece probable que el gobierno o el parlamento autonómicos lo interpusieran pues ambos formaría la mayoría que aprobó la norma. Sólo cabe imaginar un recurso proveniente del Presidente del Gobierno central o de cincuenta diputados o de cincuenta senadores, así que la impugnación provendría de órganos estatales contra leyes autonómicas, en el caso catalán ya revisadas por el Consejo Consultivo. Más parecería tales recursos intromisiones en el autogobierno. 
Queda la cuestión de inconstitucionalidad que sí podría emplearse con cierta naturalidad, pero tendríamos antes que admitir ese desdoblamiento del TC y el ensanchamiento del bloque de la constitucionalidad, dos premisas difíciles de aceptar.

De las garantías extrajurisdiccionales, acaso la más importante sea la brindada por el defensor del pueblo, institución que, aparte de existir la escala estatal (artículo $54 \mathrm{CE}$ ), opera en varias CCAA y que dos de la reformas aprobadas, la canaria y la balear, la han introducido en sus sistemas institucionales. Hasta la fecha los defensores del pueblo autonómicos defendían los derechos constitucionales frente a los poderes públicos autonómicos, ahora tendrán que ocuparse también de la tutela de los derechos estatutarios.

Lo natural sería fuera que los defensores autonómicos sólo se encargaran de la defensa de los derechos estatutarios frente a los poderes públicos autonómicos. Lo segundo, en efecto, acontece y todos ellos vigilarán únicamente la actividad de los poderes públicos propios. Sin embargo, en todos los nuevos estatutos de los que nos ocupamos ahora, se mantiene la defensa de los derechos constitucionales y así lo expresan los preceptos correspondientes (artículo 78.1 del Estatuto de Cataluña, artículo 38 del Estatuto de Valencia, artículo 128.1 del Estatuto andaluz, artículo 18.1 de la propuesta castellana leonesa y los artículos y 51.1 de la propuesta castellano manchega). En el Estatuto balear hay una genérica mención a los derechos fundamentales y libertades públicas (artículo 50) que debe entenderse en sentido abarcador de los derechos estatutarios. Sólo el artículo 59.1 a) del nuevo Estatuto de Aragón atribuye al Justicia de Aragón la defensa de los derechos estatutarios sin mención de los constitucionales. Con esta sola excepción el resto de los defensores del pueblo autonómicos comparten con el Defensor del Pueblo estatal la defensa de los derechos constitucionales frente a los poderes públicos autonómicos, quedando reservada al estatal la defensa de los derechos constitucionales frente a los poderes públicos estatales.

En definitiva, cuando la defensa se brinda frente a los poderes autonómicos, la tutela de los derechos constitucionales puede pretenderla el ciudadano alternativamente tanto del defensor autonómico como de defensor estatal. No se priva, pues, al defensor estatal de la posibilidad de revisar la actividad de los poderes públicos autonómicos. Hay, sin embargo, una excepción ${ }^{144}$ a esta regla, la contenida en el artículo 78.1 del Estatuto de Cataluña que atribuye al Sindic de Greuges "la supervisión con carácter exclusivo" de la actividad de la administración autonómica, aunque tal supervisión se destine a la protección de los derechos constitucionales. En otras palabras, se excluye la posibilidad de elegir y, en consecuencia, la intervención del defensor estatal. Los ciudadanos catalanes sólo podrán recabar la protección de los derechos constitucionales, frente a la actividad de la administración catalana, ante el

144 Dejando a un margen el texto del art. 51.1 de la propuesta castellano manchega que se refiere, en plural, a las administraciones públicas, pero que no excluye (lo que sí hace el Estatuto catalán) la supervisión del Defensor del Pueblo estatal. 
Sindic. Únicamente podrán los ciudadanos de Cataluña solicitar la intervención del defensor estatal si invocan derechos constitucionales frente a la actividad de la administración del Estado presente en Cataluña, por ejemplo la de justicia. El modelo catalán de exclusividad de protección de los derechos constitucionales y estatutarios frente a la administración autonómica diverge del tipo común que sí permite al defensor estatal supervisar a la administración autonómica respectiva cuando el quejoso invoca derechos constitucionales. Tal exclusión de sus facultades de supervisión ha sido uno de los motivos de impugnación esgrimidos por el Defensor del Pueblo estatal en su recurso de inconstitucionalidad contra el Estatuto catalán.

La única manera, y aun ésta discutible, de cohonestar la previsión estatutaria con el derecho estatal sería modificando la Ley Orgánica del Defensor del Pueblo. Al hacerlo se daría una interpretación distinta a la artículo 54 CE, interpretado hasta ahora en el sentido de que el Defensor del Pueblo estatal podía supervisar la actividad de toda administración pública, incluidas las autonómicas. En la modificación legislativa que sería necesaria, tal posibilidad debería mantenerse puesto que los viejos estatutos y también todos los nuevos, salvo el catalán, permiten la supervisión de la actividad de su propia administración, pero al mismo tiempo esta posibilidad se tendría que hacer depender de la previsión estatutaria concreta; si ésta la excluye, como hace el Estatuto catalán, entonces el defensor estatal no podría intervenir. Habrá en este punto que estar a lo que el TC decida.

\section{CONCLUSIONES}

Las declaraciones estatutarias elevan el rango de las desigualdades de trato que ya se habían producido mediante la incidencia de la legislación autonómica en el ejercicio de los derechos. Las diferencias y asimetrías ya existentes se amplían y se consagran en las normas cimeras de los respectivos ordenamientos autonómicos. Coexistirán estatutos sin declaraciones y estatutos con declaraciones diferentes. ${ }^{145}$ El mínimo de protección seguirá siendo el brindado por la Constitución y la legislación estatal, mínimo que no podrá ser rebajado por las CCAA.

Algunos estatutos expresamente dotan a los derechos declarados de todos los rasgos propios de los derechos fundamentales. Los demás, sin caracterizarlos así, parecen discurrir en la misma senda. Sin embargo, no son derechos constitucionales sino un nuevo tipo de derechos: los derechos estatutarios, categoría dogmática novedosa a la que deberemos acostumbrarnos y acerca de la cual habremos de teorizar. ${ }^{146}$ En este sentido parece prudente construir una

145 GARCÍA ROCA es partidario de que todos los estatutos acaben disponiendo de su propia declaración, pues de lo contrario se crearían asimetrías indeseables, "El riesgo...", ob. cit., p. 106.

146 GARCÍA ROCA anticipa los numerosos problemas de exégesis que presenta la declaración estatutaria, aunque, a juicio de este autor, tales problemas no sean irresolubles, "El riesgo...", ob. cit., pp. 101. 
categoría compacta, un concepto de derecho estatutario que comprendiese a todos los que se declarasen, y evitar que de cada estatuto haya que extraer un concepto distinto. El pluralismo, la asimetría tolerable, es la de los contenidos posibles de los derechos, no la de su continente. Todo derecho estatutario valdría lo mismo en su respectivo ámbito. No parece, pues, posible que el TC rebaje la categoría de las normas que proclaman estos derechos para considerarlos meros principios programáticos.

Las declaraciones estatutarias, como algunos estatutos disponen $-\mathrm{y}$ no podría ser de otra manera- no menoscaban las competencias estatales, en especial la contenida en el artículo 149.1.1 CE ni las funciones atribuidas al legislador orgánico ex artículo 81.1 CE. Otra cosa es que la definición de las competencias estatutarias que realiza el Estatuto catalán pretenda condicionar el despliegue de las competencias estatales, entre ellas la recogida en el artículo 149.1.1 CE. ${ }^{147}$

No es lo mismo declarar derechos que desarrollarlos. Parece claro que, cuando el legislador estatuyente declara derechos, no ejerce la función de desarrollarlos prevista en el artículo 81.1 CE ni fija condiciones básicas del ejercicio de los derechos y del cumplimiento de los deberes constitucionales (artículo 149.1.1 CE). En ambos casos la ley estatal —orgánica u ordinariadebe ser general, para todos los españoles, y no de ámbito restringido como son los estatutos.

De los artículos 81.1, 149.1.1, 138.2 y 139.1 de la Constitución no se infiere prohibición al legislador estatuyente para declarar derechos, aunque tanto sobre él como sobre el legislador autonómico se proyecten las citadas cláusulas. La declaración estatutaria no menoscaba la integridad normativa de los preceptos constitucionales citados.

Así las cosas, el debate en torno a la legitimidad de las declaraciones estatutarias de derechos tiene que girar en torno al artículo 147 CE. Hay que admitir que ninguna referencia constitucional al estatuto se aparta de lo orgánico y procedimental, lo que encaja perfectamente con la función institucional a él asignada por el apartado 1 del artículo $147 \mathrm{CE}$. Las materias mencionadas en el apartado segundo del artículo 147 CE describirían su contenido mínimo, obligatorio, mientras que las otras referencias constitucionales conformarían el contenido posible. Ambos se remitirían a esa función institucional del estatuto, servir de norma institucional básica de la comunidad autónoma respectiva.

En definitiva, si admitimos que del artículo $147 \mathrm{CE}$, junto con otras referencias expresas a los estatutos que encontramos en la Constitución, puede inferirse un contenido constitucionalmente tasado de la reserva a favor de estatuto, entonces el debate concluiría en la inconstitucionalidad de toda declaración estatutaria de derechos.

147 Por que, como afirma Luis ORTEGA ÁLVAREZ, los estatutos no pueden limitar las competencias que la Constitución reserva al Estado, «la redefinición por los Estatutos de Autonomía de la distribución territorial del poder contemplado en la Constitución", en ORTEGA ÁLVAREZ, ob. cit., pp. 16 y ss. 
Existe, empero, un resquicio a través del cual podemos argumentar que las declaraciones estatutarias son constitucionales si desvelan una función institucional: limitar, orientar e impulsar la acción de los poderes públicos autonómicos. Tal función institucional exigiría la conexión de cada derecho declarado con alguna competencia de la CA respectiva. De esta suerte, la declaración es legítima si sobre el ámbito de ejercicio de los derechos declarados la comunidad respectiva posee competencias. La posibilidad de declarar derechos se integraría así en el derecho a la autonomía proclamado en el artículo 2 de la Constitución.

Según lo anterior, es lógico que las declaraciones estatutarias no contengan referencia alguna a muchos derechos constitucionales, en cuyos ámbitos de ejercicio las CCAA carecen de competencias. Ahora bien, sobre los derechos estatutarios y la legislación autonómica de desarrollo pesarán la declaración constitucional y las leyes estatales de desarrollo.

La pretensión de los estatutos no es, pues, declarar todos los derechos posibles sino aquellos ligados a las competencias de la CA respectiva. En este sentido la duplicación de declaraciones - constitucional y estatutarias - no equivale a una completa federalización de los derechos - potencial duplicación- sino a un complemento de la estatal en aquellos ámbitos donde las CCAA son competentes.

La complementariedad pretendida que, en todo caso, habrá de alcanzarse, plantea problemas de articulación que tendrán que disiparse. Para comenzar, la protección brindada por las CCAA, aunque se contenga en normas competentes, no podrá rebajar el nivel de protección brindado por la legislación estatal. Como esta puede variar — mejorar-, al ejercer el Estado sus competencias, las CCAA deberán adaptar su ordenamiento infraestatutario.

Plantea problemas asimismo la garantía de los derechos estatutarios. Respecto de la tutela jurisdiccional, las CCAA carecen de un poder judicial propio al que puedan encargar esta tarea, y no pueden regular sus procedimientos concretos. Algunos estatutos se refieren a futuras vías judiciales — con mayor especificidad el Estatuto catalán y su "recurso de amparo»—. En todo caso, será el legislador estatal el que deba regular tales procedimientos.

Configurado un modelo de doble protección, el ciudadano tendrá entonces dos vías a su disposición: la existente para la defensa de sus derechos constitucionales que concluiría, en su caso, en el recurso de amparo ante el TC, y la vía de defensa de los derechos estatutarios. Podía acudir a una u otra, alternativamente, si los derechos estatutarios tuvieran - como tienen a menudo- su replica en la legislación estatal.

También complicado es imaginar un control de "estatutoriedad" de las leyes autonómicas por infracción de preceptos estatutarios reconocedores de derechos. Como el TC ostenta el monopolio del control de las normas con valor de ley, a él debería en principio reconocérsele esta función que ningún otro órgano puede desempeñar. Sin embargo, ello supondría que las declaraciones estatutarias, que no vinculan al Estado sino sólo a los poderes públicos autonómicos, pasarían a formar parte del bloque de la constitucionali- 
dad como forman parte de él las normas estatutarias que distribuyen competencias y que sí vinculan al Estado. Se ensancharía así el canon de enjuiciamiento del TC que se convertiría, al enjuiciar leyes autonómicas para verificar su respeto de los derechos estatutarios, en una suerte de TC de la CA respectiva y de todas si el sistema se generalizase. Esto no tiene apoyo ni en la Constitución ni en la LOTC. No me parece plausible ni legítima esta desnaturalización del TC que además convertiría a los derechos estatutarios en verdaderos derechos constitucionales, defendidos por el TC frente al legislador autonómico, aunque no frente al legislador estatal.

Bien es cierto que la postura defendida provoca impunidad de las leyes autonómicas contrarias a los derechos de los estatutos y que, entonces, sólo un hipotético control previo, que únicamente contempla el Estatuto catalán, residenciándolo en el Consejo de Garantías Estatutarias, serviría para esa defensa. Para solventar el problema, la única solución, a mi juicio, consistiría en modificar la LOTC para atribuir al TC funciones de "Tribunal constitucional autonómico".

Habrá que aguardar la sentencia del TC que resuelva los recursos de inconstitucionalidad interpuestos contra el Estatuto catalán. Si admitiese la constitucionalidad de declarar derechos en los estatutos, habría consagrado una radical novedad que me atrevo a calificar de mutación, modificando el entendimiento que hasta ahora se ha tenido de los estatutos de autonomía y de nuestro sistema de derechos. Tiempo costará entonces reacomodar las piezas de este rompecabezas que ahora apenas estamos vislumbrando.

ABSTRACT. The incorporation of a Bill of Rights in each new Statute of Autonomy, recently approved, suppouses a radical novelty in Spain. In a way, "federalizes" the Spanish System of Rights, far away from the Unitary States. From now on will co-exist two levels of Bill of Rights: Constitucional and Autonomic. It does not implies specific competences to the Autonomic Communities, but will do require a big effort from all jurists to clear up the many doubts of this new situation; are these true rights?; how can we protect them? 